\title{
İmam-Hatip Liseleri Üzerine Kapsamlı bir Literatür Taraması
}

\author{
Merve Kaya ${ }^{1}$ Ayşe Hümeyra Bilgü ${ }^{2}$ Sümeyye Kuşakc1 ${ }^{3}$
}

\begin{abstract}
Özet
İmam hatipler toplumun dini hizmetlerinin karşılanması amacıyla açılmış, milletin büyük teveccühü ile Türk eğitim sisteminin mütemmim bir cüzü olmuştur. Ancak zamanla politik tartışmaların merkezinde kalan bu okullar zorlu süreçlerden geçmiştir. Siyaset, sosyoloji, pedagoji, psikoloji gibi çok farklı disiplinlerde bu okulları ele alan birçok bilimsel çalışma ortaya konmuştur. Bu makale imam hatiplere ilişkin Türkçe ve İngilizce yazılmış tez ve makaleleri inceleyerek mevcut literatüre dair bazı tespitler yapmayı hedeflemektedir.

Çalışma kapsamında İmam hatip okullarını ele alan 219 araştırma değerlendirilmiş, taranan eserler konularına göre 10 ana başlık altında sınıflandırılmıştır. Tespitlerimize göre, bu alandaki akademik çalışmaların büyük bir kısmı 2011-2020 yılları arasında hazırlanmıştır. Türkçe yayınların daha çok müfredat ve derslerin içeriklerine yönelik olduğu görülürken, İngilizce makaleler konuya ağırlıklı olarak sosyo-politik bir tartışmanın merceğinden bakmıştır. Makalede önemli görülen bazı çalışmalar detaylı şekilde irdelenmiş, son olarak yeni yapılacak çalışmalara yönelik tavsiyeler paylaşılmıştır.
\end{abstract}

\section{Anahtar Kelimeler}

İmam Hatip Okulları, İmam Hatip Liseleri, İmam-Hatip Yazını, Din Eğitimi.

1 Yetkilendirilmiş yazar: Yüksek Lisans Öğrencisi, Marmara Üniversitesi, İlahiyat Fakültesi, İslâm Felsefesi Ana Bilim Dalı, kmrv.009@gmail.com, ORCID ID: 0000-0001-9870-7300

2 Yüksek Lisans Öğrencisi, Marmara Üniversitesi, İlahiyat Fakültesi, İslâm Hukuku Ana Bilim Dalı, ORCID ID: 0000-0003-3443-1864

3 İbn Haldun Üniversitesi, Yönetim Bilimleri Fakültesi, İşletme Bölümü, ORCID ID: 0000-00029493-2591 


\title{
A Comprehensive Literature Review on Imam Hatip High Schools
}

\author{
Merve Kaya Ayşe Hümeyra Bilgü Sümeyye Kuşakcı
}

\begin{abstract}
Imam hatip schools were opened with the aim of meeting the religious services of the society, and became an important part of the Turkish education system with the great favor of the Turkish people. However, these schools, which have been at the center of political discussions over time, have gone through difficult processes. Many scientific studies addressing these schools in many different disciplines such as politics, sociology, pedagogy and psychology have been put forward. This article aims to make some determination about the current literature by examining the Turkish and English articles and master and doctoral theses about imam hatip shools.

Within the scope of the study, 219 studies dealing with Imam hatip schools were evaluated, and the scanned works were classified under 10 main titles according to their subjects. Based on the findings of the study, most of the academic studies in this field were prepared between 2011-2020. While Turkish publications seem to be more focused on the content of the curriculum and lessons, English articles looked mainly at the subject from the lens of a socio-political discussion. Lastly, some of the important works in the article were examined in detail, and recommendations for new studies were shared.
\end{abstract}

\section{Key Words}

İmam Hatip Schools, İmam Hatip High Schools, Literature Review, Religious Education.

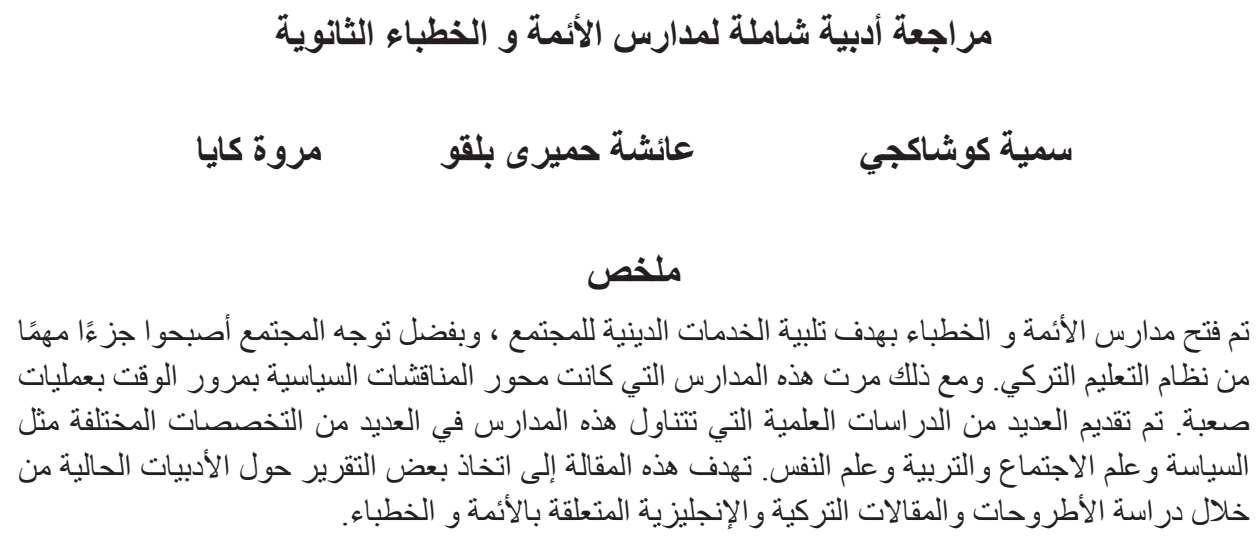




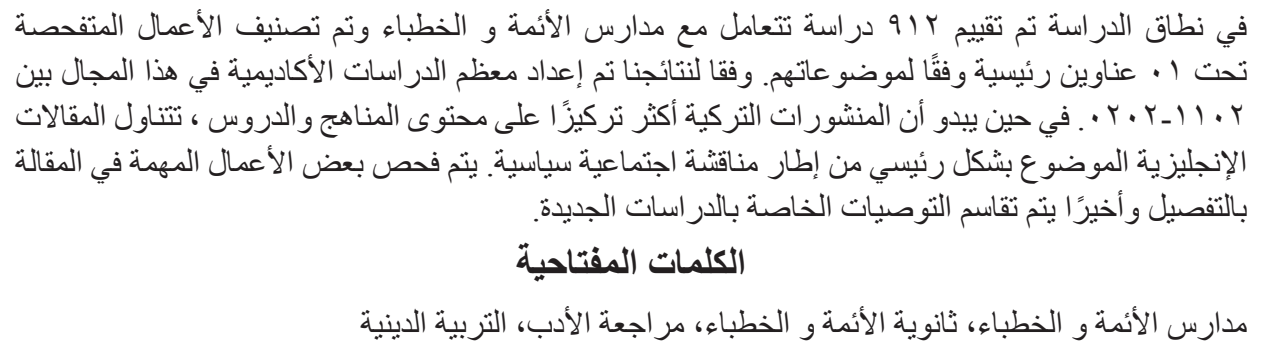

\section{Giriş}

Toplumların hayatında eğitim çok önemli bir yere haizdir. Türk eğitim sistemi özgür ve sorgulayan, farklılıklara saygı duyan, din, dil, ırk ayrımı gözetmeksizin eşit insanların bulunduğu bir topluma saygı gösteren bireyler yetiştirmeyi amaçlamaktadır. Din eğitiminin bu amaç önünde bir engel teşkil ettiği düşüncesi ile pozitif bilimlerin yanında dini eğitimin verilmesi fikri uzun yıllar milli eğitim politikalarının bir parçası olamamış, din eğitimi politikaları istikrarlı bir temele oturtulamamıştır. Nitekim Türkiye'de örgün öğretimde dini konuların öğretilmesi konusunda Cumhuriyet tarihi boyunca farklı uygulamalara da başvurulmuştur. Bu uygulamalardan en dikkat çekeni imam hatipler olmuştur.

Cumhuriyet döneminde kurulan imam hatip okullarının eğitim sisteminin önemli bir parçası olduğu inkâr edilemez. İlk kurulduğu dönemde ve sonrasında adından sıkça söz ettiren bu okullar kuruluşu, müfredatı ve üzerlerinden yürütülen siyasi tartışmalar ile sık sık gündeme gelmiştir.

Türkiye'de din eğitiminin müesseseleşmiş hali olan imam hatip liselerinin kuruluşu üzerinden 69 yıl geçmiştir. Bu sürecin ilk adımı olarak Tevhid-i Tedrisat kanununun 4. Maddesi kararınca 29 İmam Hatip mektebi açılmışsa da, 1927 yılında 18'i kapatılmış yenileri açılmamıştır. 1930 yılının sonuna doğru kalan imam hatipler öğrenci yokluğu gerekçesiyle işlevsiz kalmış; 1929-1930 öğretim yılında resmen, 1931-1932 öğretim yılı sonunda fiilen kapatılmışlardır. Bu minvalde dini eğitimin bir diğer veçhesi Tevhid-i Tedrisatla kurulan Daru'l-fünun İlahiyat Fakültesidir. Ancak bu fakülte de imam hatip okulları ile aynı zaman diliminde kapatılmıştır. Böylelikle Türkiye Cumhuriyeti'nde 1930’lu yılların başından 1950'li yıllara kadar din eğitimi ve öğretimi yasaklanmıştır (Öcal, 1998). İmam hatip okullarının kapatılmasıyla dini eğitimin bir şekilde yasaklanması, dini hayata yapılan baskı ve müdahalelerin bir nişânesi haline gelmiştir. $\mathrm{Bu}$ müdahaleler sadece eğitim alanını etkilememiş, söz konusu yasak sosyal hayatta da bazı olumsuzluklara yol açmıştır. Yok sayılan dini otoritenin yerini batıl akidelerin alması kolaylaşmıştır. Ülkede cenaze kaldıracak din görevlisi bulunamaz hale gelmiş; dolayısıyla imam hatiplerin yeniden açılması kaçınılmaz bir hal almıştır. 1949'da açılan imam hatip kursları talebin yetersiz olduğu gerekçesiyle 10 ay sonra kapatılmıştır. 
Y1l 1950'yi gösterdiğinde Demokrat Parti'nin başa geçmesiyle birlikte imam hatip okullarına dönük olumlu bir bakış açısı gelişmiştir (Öcal, 1998). 1951 yılında ise fiilen ilkokula dayalı yedi yıllık imam hatip okulları tekrar açılmışıtır. İmam hatip okulları halkın yüksek ilgisine matuf olmuş ve öğrenci mevcudunda ciddi bir artış söz konusu olmuştur. 28 Şubat 1997 yılında alınan kararlar ile birlikte imam hatip okullarının sekiz yıllık kesintisiz eğitim kapsamına alınması, ortaokul kısımlarının kapatılması ve üniversiteye girişte katsayı uygulanması bu pozitif trendi tersine çevirmiştir. 28 Şubat kararlarının etkisi ancak 2003 yılından sonra kırılabilmiş, imam hatip okullarının öğrenci sayıları tekrar artmıştır. MEB'in son on yılı esas alan çalışmasına göre imam hatiplerdeki öğrenci sayısı 5 kat artmıştır.

Tüm lise ve meslek lisesi öğrencileri içindeki imam hatip öğrencilerinin payı orantılı olarak artmaktadır. İmam hatip liselerindeki öğretmen sayısı 10 yılda 4 kat artmıştır.

Bu bilgiler arasında asıl ilgi çekici olan, katsayı probleminin kalktı̆̆ı 2012 -2013 eğitim yılında 708 imam hatip lisesinde 380 bin 371 öğrenci okurken, 2018-2019 yılında 1624 imam hatip lisesine 604 bin 869 öğrencinin kayıt olmuş olmasıdır (Milli Eğitim Bakanlığı, 2019). Bu rakamlar, katsayı ve başörtüsü yasakları gibi uygulamaların kalkması ile birlikte bu okulların tekrar ciddi ilgiye mazhar olduklarını göstermektedir.

İmam hatip okulları kurulduğundan bu yana iki farklı bakış açısı ile değerlendirilmiştir. Bazı kesimler bu okullara mesafeli ve olumsuz tavır almışken; bazı kesimler son derece olumlu ve sıcak bir tavır sergilemiştir. Olumsuz bakan kimseler ekseriyetle bu okulları laikliğe karşı bir tehdit olarak görmüşlerdir (Çakmak, 2009; Can, 2017; Öcal, 1998). Oysa imam hatip okulları 1924'te yürürlüğe giren Tevhid-i Tedrisat kanununun 4. Maddesinin hükmü gereği açılmışken laiklik 1928 'de fiilen uygulanmaya başlamış; ancak 1937 'de anayasal bir madde haline gelmiştir. Geçmişten bugüne imam hatip okulları sürekli siyasi bir bakış açısıyla ele alınmış ve bu yönde olumlu veya olumsuz eleştirildiği için asıl ele alınması gereken eğitim ekseni 1skalanmıştır. Siyasi veçhesiyle ele alınan imam hatip okulları yıllar boyunca farklı fikir ve ideolojilerin üzerinden kanaat bildirdiği bir konu olmuştur (Deniz, 2014). Bu yaklaşım medyanın dilinde açıkça göze çarpmaktadır (Önder İmam Hatipliler Derneği, 2018).

Cumhuriyetin ilanından günümüze kadar kesintilerle de olsa var olmayı başaran imam hatip okulları, en çok tartışılan eğitim müesseseleridir. Mevzubahis okulların bu denli tartışılması ve haklarında olumlu/olumsuz düşünce beyan edilmesi, imam hatip okullarını konu edinen akademik çalışmaların bilimsel niteliklerinin yeterliliği ve keyfiyeti hakkında güncel bir literatür taraması ihtiyacını doğurmuştur. Bu çalışmada imam hatip okulları hakkında 2011 yılında yapılmış bir literatür taraması (Kaymakcan \& Aşlamacı, 2011) esas alınmış ve bu araştırmanın yapılan yeni çalışmaları da kapsayacak şekilde güncellenmesi hedeflenmiştir.

Yukarıdaki tespitler ışı̆̆ında bu çalışmanın alandaki yazın birikimine katkısı aşağıdaki gibi sıralanabilir. Çalışma imam hatip okullarının akademik anlamda nasıl ele alındığını on genel kategoriye ayırarak ortaya koyacaktır. Ayrıca bu makale tez, Türkçe makale ve uluslararası mecralar yayınlanmış İngilizce makaleler olmak üzere 
imam hatipler üzerine yapılan çok çeşitli bilimsel çalışmaları tarayan çok kapsamlı bir çalışmadır. Bunun yanında makalede taranan çalışmaların konuları gruplandırılmış ve akademik olarak yeteri kadar tartışılmamış konular belirlenip bu bilgi araştırmacıların istifadesine sunulmuştur.

Çalışmanın bundan sonraki kısmı şu şekilde düzenlenmiştir. İkinci bölümde imam hatipler üzerinde yapılan bilimsel çalışmalara ilişkin genel bir bakış verilmiş; üçüncü bölüm incelenen eserlerin sınıflandırılmasına ayrılmıştır. Dördüncü bölümde konu hakkında yazılmış ve dikkat çeken çalışmalara ilişkin daha detaylı bilgi sunulmuştur. Son olarak beşinci bölümde çalışmanın çıktıları değerlendirilmiş, konuyla ilgili yapılacak yeni araştırmalar için bilimsel literatürdeki boşluklar tespit edilmiştir.

\section{İmam Hatipler Üzerine Yapılmış Akademik Çalışmalara Genel Bakış}

Daha önce de belirtmiş olduğumuz gibi 1951-2011 yılları arasını ihtiva eden imam hatipler üzerine Kaymakcan ve Aşlamacı (2011) tarafından yapılmış olan literatür taraması çalışmasını da dikkate alınarak, YÖK Tez Merkezi'nde "İmam Hatip", "İmam-Hatip" anahtar kelimeleriyle yapmış olduğumuz 1989-2020 yıllarını kapsayan taramanın sonucu Şekil 1'de verilmiştir.

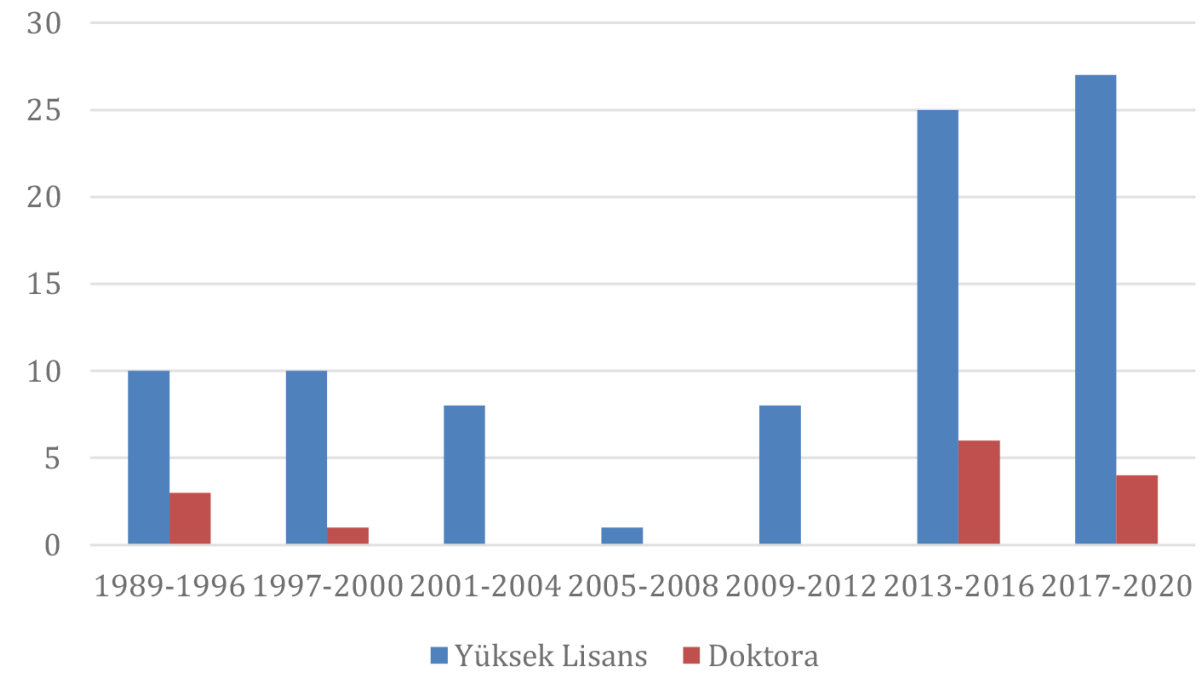

Şekil 1

Tez türlerine ve yıllara göre çalışmaların dağıllımı

Buna göre 1989-2020 yılları arasında tamamlanmış imam hatip okullarını konu alan tez çalışmaları toplamda 103'dir. Bu 103 lisansüstü tezin 89'ü yüksek lisans tezi iken, 14'ü doktora tezidir. Şekil 1'e göre yapılabilecek ilk tespit; 2009 yılında imam hatip okullarındaki katsayı problemi kaldırıldıktan sonra bu okulları odağına alan lisansüstü çalışmalarda ciddi bir artış söz konusu olduğudur. Bizce bu tip çalışmaların net bir 
şekilde artmasının iki sebebi vardır. Bunlardan ilki, ilahiyat fakültelerinin sayısının artmasıyla bu fakültelerdeki araştırmacıların din eğitimine bilimsel bir bakış kazandırma çabasıdır. Nitekim gösterilen çaba nicel verilere de yansımıştır. İkinci sebebi ise; imam hatip okullarına karşı siyasi düzeyde çeşitli olumlu veya olumsuz söylemlerin olmasıdır. $\mathrm{Bu}$, imam hatip okullarını gündeme getirmiş ve akademik çalışmalara konu olmasına sebep olmuştur.

Sürekli konuşulan, tartışılan, müspet veya menfi eleştirilere muhatap olan imam hatip okullarının eğitimdeki yeri akademik camiayı da etkilemiş ve harekete geçirmiş görünmektedir.

Doktora tezi olarak imam hatiplerle ilgili yapılmış çalışmaların en yoğun olduğu zaman dilimi 2013-2016 yılları arasına tekabül etmektedir. Söz konusu yıllar arasında yapılmış olan 6 doktora tezi bulunmaktadır.

Yüksek lisans ve doktora tezleri ile birlikte yer vermek istediğimiz bir diğer akademik yazım biçimi makalelerdir. Dergipark ve İSAM makaleler veri tabanı ekseninde yapmış olduğumuz tarama sonucu ulaştığımız makalelerin dağılımı aşağıdaki gibidir.

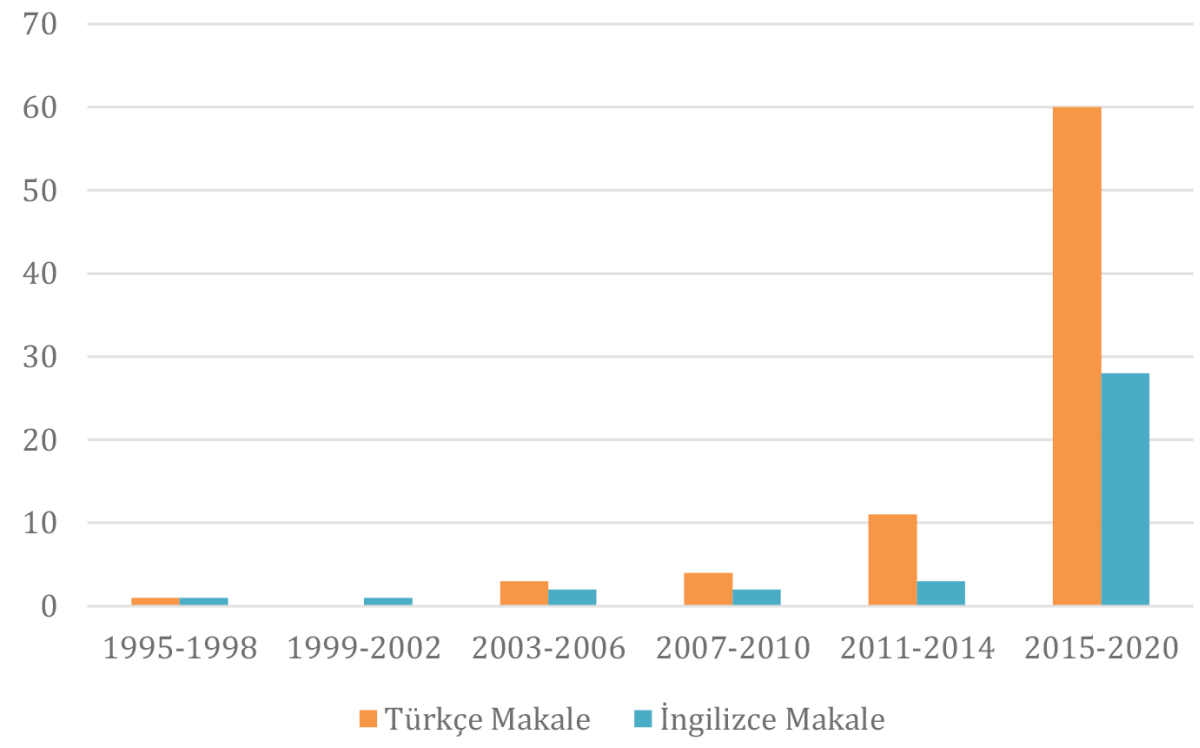

Şekil 2

Yıllara göre makalelerin dă̆ılımı

1995-2020 yılları arasında imam hatipler üzerine yayımlanmış olduğunu tespit edebildiğimiz makale sayısı Şekil 2'de gösterildiği gibi 116'dır. Bu makalelerin 79'unu Türkçe makaleler oluştururken, 37'si İngilizce yazılmış makalelerdir. Serdettiğimiz yıl aralıklarını baz aldığımızda Türkçe makalelerin rağbet görmeye başladığı yıl 2011'dir. 
Makale sayısı 2011-2014 yılları arasında 10 iken, 2015-2020 yılları arasında bu sayının yaklaşık olarak beş katı makale yayınlanmıştır. Akademik anlamda böylesi ciddi bir artışın temel sebebini katsayı probleminin giderilmesinin gündemde yer bulması olarak değerlendirmekteyiz. Bu problem ve çözüm arayışları yıllardır bir şekilde görmezden gelinen imam hatipleri gündeme taşımıştır. Öyle görünüyor ki bu merak akademik camiaya da sirayet etmiş, bu ciddi artışın sebebi olmuştur.

Nitekim 2003 yılında yazılmış bir makale imam hatipler hakkında o zaman mevcut olan tasavvuru gözler önüne sermiştir. Söz konusu bu tasavvur katsayı probleminden sonra çeşitli tez ve makale çalışmalarında da incelenmeye çalışılmıştır. Siyasal İslam tartışmalarının gündeme geldiği zamanlarda imam hatipler dini çizgileri nispetinde bu tartışmalardan nasibini almıştır. İmam hatip okullarının "siyasal islamcıların" yetiştirildiği okullar olduğu iddiasını ele alan makale, bu iddianın asılsız olduğu sonucuna ulaşmıştır. Yazarlar "siyasal islamın" yükselişte olduğu bir dönemde bu okulların hedef alınıp "siyasal islamcılığın” menşei olarak görülmesini bilimsel bir yaklaşım olarak değerlendirmemişlerdir. Çünkü "siyasal islamcılığı" direkt imam hatipler üzerine yıkmak bu olgunun ortaya çıkmasında asıl rolü olan diğer sosyolojik faktörleri yok saymak demektir. Özetle, bir tespitin bilimsel bir gerçek olması konunun tüm boyutlarının araştırılıp incelenmesini gerekli kılmaktadır (Erkan \& Akçayöz, 2003).

Şekil 2’de görüldüğü üzere İngilizce yapılan çalışmalar 2015 yılından sonra ivme kazanmıştır. İmam hatiplere akademik dünyada uluslararası ilgi okulların ilk açıldığı döneme kadar uzanmaktadır. (Reed, 1955). Bunun yanında tespit edilen uluslararası dergilerde yayınlanmış 37 makalenin büyük çoğunluğu 2015 sonrası yazılmıştır. Bu tespit, alana ilgilinin ve yapılan çalışmaların içeriği konusunda da ipuçları vermektedir. Katsayı uygulaması ve başörtüsü yasağının kalkması ile başlayan pozitif ivme yurtdışında genelde Türk eğitim sisteminin Batı'dan kopması olarak görülmüş ve politik bir tartışmanın etrafında şekillenmiştir (Çakmak, 2009; Gontijo \& Barbosa, 2020; KarlidagDennis, McGrath, \& Stevenson, 2019). Bu okullardaki iyi uygulamaları uluslararası alanda tanıtmak ve Türkiye'nin eğitimi iyileştirmeye ve demokratikleştirmeye yönelik çok yönlü politikasının bir parçası olarak gören sayılı çalışma olmasına rağmen (Z. Çelik \& Gur, 2013; Gür, 2016; Koç \& Bastas, 2019; H. E. Suna, Tanberkan, Gür, Perc, \& Özer, 2020) uluslararası çalışmaların çoğu son yıllarda imam hatiplere yönelik eğitim politikalarını Batı'dan kopma ve seküler eğitim modeline bir tehdit olarak sunmuştur.

\section{İmam Hatipler Üzerine Yapılan Çalışmaların Sınıflandırması}

İmam hatip okullarına odaklanan çalışmalar incelendiğine araştırmacıların imam hatip okullarını çok yönlü bir bakış açısıyla ele aldıkları sonucuna ulaşılmıştır. Yapılan tarama süresinde ilk aşamada ilgili çalışmalar tezler, Türkçe makaleler ve İngilizce makaleler olmak üzere üç ana gruba ayrılmıştır. İkinci aşamada bu üç grup altında incelenen yazınların konularına göre aşağıda sıralanan on başlık altında toplanması uygun bulunmuştur: 
- İmam hatiplilik algısı: İmam hatip öğrencisinin gözünden okulu, öğretmenleri ve imam hatiplilik algısını irdeleyen çalışmalar bu grupta toplanmıştır.

- Psikoloji/din psikolojisi açısından imam hatip öğrencisi: İmam hatip öğrencisinin çeşitli konulardaki motivasyonu, psikolojik iyi oluşu ve Allah algısı gibi konuları ele alan çalışmalar bu gruba alınmıştır.

- İmam hatip okullarında müfredat ve öğretim: Okullarda okutulan müfredat ve derslere ilişkin yayınlar bu gruba dâhil edilmiştir.

- Öğretmen ve yöneticiler: Öğretmenlerin ve yöneticilerin yetkinlikleri ve sorunlarını inceleyen çalışmalar bu grupta toplanmıştır.

- İmam hatiplerin yetkinliği: Okulların ve öğrencilerin belli konularındaki yetkinliğini sorgulayan çalışmalara bu grupta yer verilmiştir.

- Tarihsel bağlam açısından imam hatipler: İmama hatip okulları özelinde din eğitimini tarihsel bağlamında ele alan çalışmalar bu grupta toplanmıştır.

- İmam hatip okullarının diğer paydaşları: İmam hatip okullarının paydaşı olan veli, okul aile birlikleri ve diğer sivil toplum kuruluşlarını konu alan çalışmalar bu gruba dâhil edilmiştir.

- Sosyo-politik bir olgu olarak imam hatipler: Konuyu esas itibariyle sosyolojik ve/veya politik yansımaları açısından ele alan yayınlar bu gruba alınmıştır.

- Karşılaştırmalı çalışmalar: İmam hatiplerin çalışmanın ana konusu olmadığı ancak diğer okul türleri ile karşılaştırma yapılarak çalışmanın önemli bir parçası olduğu yayınlara bu grupta yer verilmiştir.

- Bibliyografik çalışmalar, kitap incelemeleri: Son olarak, imam hatipleri konu alan yayın taraması ve kitap incelemeleri bu gruptadır.

Şüphesiz, bu gruplandırma eldeki çalışmalar göz önüne alınarak öznel bir tercih ile yapılmıştır. Farklı araştırmacılar farklı gruplandırmalar da yapabilirler. Bunun yanında bazı çalışmaları eserin kapsamı gereği kesin olarak bir gruba dâhil etmek de oldukça güç olmuştur. Bundan dolayı aynı eseri birden fazla kez saymamak adına içerik dikkatli şekilde incelenerek, eser en uygun gruba eklenmiştir.

Çalışmada Kaymakcan ve Aşlamacı'nın (2011) yazın incelemesi de dikkate alınarak, özellikle 2011 y1lından sonra yayınlanan eserler, kitap/tez, Türkçe makaleler ve uluslararası mecralarda yayınlanmış İngilizce makaleler şeklinde incelenmiş ve Şekil 3 'te verilen dağılım grafiği elde edilmiştir. 


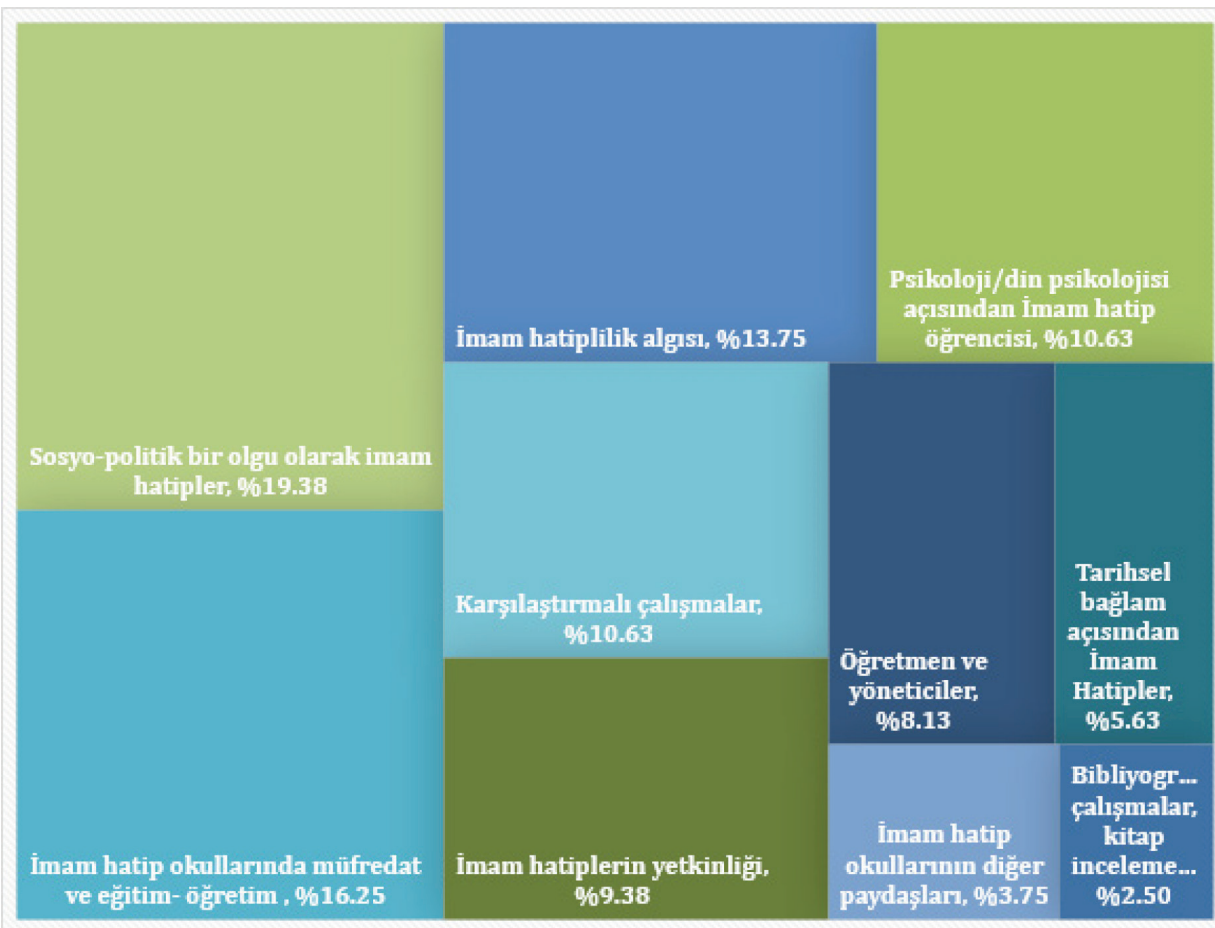

Şekil 3

İlgili alanda yazılan kitap ve tezlerin yüzdesel dağılımı

Şekle göre imam hatip okulları akademide en çok sosyo-politik bir olgu olarak incelenmiştir. İncelenen çalışmaların nerdeyse \%20'si bu başlık altında sınıflandırılabilir. İkinci ve üçüncü sırada \%15'e yaklaşan oranlarılla imam hatip okullarındaki müfredat ve imam hatiplilik algısını inceleyen çalışmalar yer almaktadır. Türkiye Cumhuriyeti’nin resmi okulları olmasına karşın sosyo-politik bir tartışma alanı olan imam hatiplerin öğrenci potansiyelini psikolojik bir bakış açısıyla inceleyen çalışmalar ise sadece \%10 düzeyindedir. Hakeza, bu okullarda yetişen öğrencilerin yetkinliği de akademinin ilgisini \%9.52 oranında çekebilmiştir. Sıralamanın sonunda yer alan başlıklar ise sırasıyla tarihsel bağlamda imam hatipler (\%5.44), imam hatip okullarının paydaşları $(\% 4.08)$ ve literatür taramaları (\%2.72) olmuştur. 
Tablo 1

Ilgili alanda imam hatip okullarını konu edinen kitap ve tez çalışmaları

\begin{tabular}{|c|c|}
\hline Alan & İlgili Kitap/Tez Çalışmaları \\
\hline İmam hatiplilik alg1s1 & $\begin{array}{l}\text { (Kanburoğlu, 2013), (Yıldırım, 2015), } \\
\text { (E. Altıntaş, 2016), (Çelik, 2016), (Aksu, } \\
\text { 2018), (Çetin, 2017), (Çalışkanoğlu, 2018), } \\
\text { (Özyiğit, 2018), (Sali, 2019), (Terlemez, } \\
\text { 2019), (Daban, 2019), (Zurnacı, 2019) }\end{array}$ \\
\hline $\begin{array}{l}\text { Psikoloji/din psikolojisi açısından } \\
\text { İmam hatip öğrencisi }\end{array}$ & $\begin{array}{l}\text { (Pehlivan, 2018), (Erikoğlu, 2019), } \\
\text { (Çekçıkar, 2019), (Çimen, 2019), } \\
\text { (Aydoğan, 2019), (Özturhan, 2019) }\end{array}$ \\
\hline $\begin{array}{l}\text { İmam hatip okullarında müfredat ve } \\
\text { öğretim }\end{array}$ & $\begin{array}{l}\text { (Aşlamac1, 2014), (Mücahit, 2016), } \\
\text { (Yaman, 2016), (Eroğlu, 2018), (Göksu, } \\
\text { 2018), (Sevilmiş, 2019), (Kocabey, 2019) }\end{array}$ \\
\hline Öğretmen ve yöneticiler & $\begin{array}{l}\text { (Boztepe, 2016), (Küçük, 2018), (Örekli, } \\
\text { 2018), (O. Aslan, 2019) }\end{array}$ \\
\hline İmam hatiplerin yetkinliği & $\begin{array}{l}\text { (Kuloğlu, 2018), (Dertli, 2019), } \\
\text { (Karasubaş1, 2019) }\end{array}$ \\
\hline $\begin{array}{l}\text { Tarihsel bağlam açısından imam } \\
\text { hatipler }\end{array}$ & (Çavdar, 2019), (Ortahisar, 2019) \\
\hline $\begin{array}{l}\text { İmam hatip okullarının diğer } \\
\text { paydaşları }\end{array}$ & (Ünal, 2008), (Kara, 2016), (Sar1, 2019) \\
\hline $\begin{array}{l}\text { Sosyo-politik bir olgu olarak imam } \\
\text { hatipler }\end{array}$ & $\begin{array}{l}\text { (Çakır, Bozan, \& Talu, 2004), (Can, 2017), } \\
\text { (Sel, 2019), }\end{array}$ \\
\hline Karşılaştırmalı çalışmalar & (Durmuşçelebi \& Deliktaş, 2016) \\
\hline $\begin{array}{l}\text { Bibliyografik çalışmalar, kitap } \\
\text { incelemeleri }\end{array}$ & \\
\hline
\end{tabular}

İmam hatipler konusunu işleyen tez çalışmalarını konularına göre gruplandırdığımızda Tablo 1'de verilen dağılım elde edilmiştir.

Yazılan kitap ve tezlerin yüzdesel dağılımı Şekil 4'te verilmiştir. Buna göre yapılan çalışmaların çoğu (\%29.27'si) imam hatiplilik algısı üzerinedir. Bunun yanında müfredata yönelik çalışmalar da geniş yer tutmaktadır. Dikkat çekici bir başka nokta okulların diğer paydaşlarına ve sosyo-politik yönüne dair çalışmalar genel dağılım ile karşılaştırılınca nispeten tezlerde daha az yer bulmuştur. 
Bibliyografik çalışmalar, kitap incelemeleri

Karşılaștırmalı çalıșmalar

Sosyo-politik bir olgu olarak imam hatipler

İmam hatip okullarının diğer paydaşları

Tarihsel bağlam açısından İmam Hatipler

İmam hatiplerin yetkinliği

Öğretmen ve yöneticiler

İmam hatip okullarında müfredat ve öğretim

Psikoloji/din psikolojisi açısından İmam hatip öğrencisi

İmam hatiplilik algısı
$\% 0.00$

$\% 2.44$

$\% 7.32$

$\% 4.88$

$\% 7.32$

$\% 9.76$

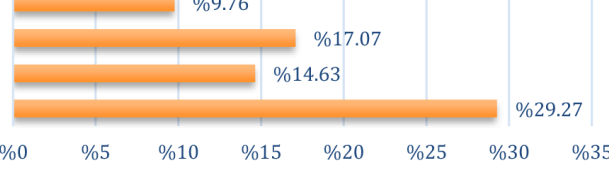

Şekil 4

Ilgili alanda yazılan kitap ve tezlerin yüzdesel dăğlımı

Benzer şekilde Tablo 2, bu okulları konu alan güncel Türkçe makaleleri sinıflandırmıştır. Buna göre son üç yılda (2018, 2019 ve 2020) imam hatip okullarına yönelik Türkçe yayınlarda ciddi bir artış olduğu görülmektedir. Makalelerin yüzdesel dağılımı dikkate alındığında nispeten dengeli bir dağılım görülmektedir (Şekil 5). İmam hatip liselerinde okutulan dersler ve bunların içeriklerine yönelik çalışmaların ağırlığı (\%19.28) ayrıca göze çarpmaktadır. Buna karşın bu okullara dair yazın incelemeleri ve bu okulların diğer paydaşlarını dikkate alan çalışmalar nadiren karşımıza çıkmıştır. 
Tablo 2

Imam hatip okullarını konu alan Türkçe makalelerin alanlarına göre dağılımı

\begin{tabular}{|c|c|}
\hline Alan & İlgili Makaleler \\
\hline İmam hatiplilik alg1s1 & $\begin{array}{l}\text { (Erkan \& Akçayöz, 2003), (Karateke, } \\
\text { 2010), (Korkmaz, 2013), (Macit, 2014), } \\
\text { (Aydemir, 2017), (Ş. Özdemir \& Karateke, } \\
\text { 2018), (Çınar, 2018), (Gencer, 2019a), } \\
\text { (Budak, 2019) }\end{array}$ \\
\hline $\begin{array}{l}\text { Psikoloji/din psikolojisi açısından } \\
\text { İmam hatip öğrencisi }\end{array}$ & $\begin{array}{l}\text { (Çekin, 2013), (Aşlamacı \& Eker, 2016), } \\
\text { (Korkut, 2017), (Ekşi, Okan, \& Ayhan, } \\
\text { 2018), (Ertaş, 2019), (Ankaralı, 2019a), } \\
\text { (Gencer, 2019b), (Aslan, 2019), (Baltacı, } \\
\text { 2019b), (Demir, 2019) }\end{array}$ \\
\hline $\begin{array}{l}\text { İmam hatip okullarında müfredat ve } \\
\text { eğitim- öğretim }\end{array}$ & $\begin{array}{l}\text { (Çınar, 2013), (Aydın \& Duran, 2014) } \\
\text { (Durmuş \& Kahraman, 2016), (Yüksel, } \\
\text { 2016), (Ertugay, 2017), (Mücahit, 2017), } \\
\text { (Keyifli, 2017), (Kara, 2017), (Apaydın, } \\
\text { 2018), (Ağçoban, 2018), (Akyüz, 2018), } \\
\text { (Kaya, 2018), (Kubat, 2019), (Batar, 2019), } \\
\text { (Akarsu, 2019), (Günay, 2019) }\end{array}$ \\
\hline Öğretmen ve yöneticiler & $\begin{array}{l}\text { (Koç, 2019), (Keyifli, 2019), (Karateke, } \\
\text { 2019), (Korkmaz, 2018), (Erdem \& } \\
\text { Alpaydın, 2017), (Baltacı, 2019a), (Baltacı, } \\
\text { 2019c), (Göcen \& Kaya, 2014) }\end{array}$ \\
\hline İmam hatiplerin yetkinliği & $\begin{array}{l}\text { (Aras \& Öztürk, 2019b), (Aras \& Öztürk, } \\
\text { 2019a), (Genç, 2019), (Emen, 2019), } \\
\text { (Gültekin, 2019), (Kervankaya, 2014), } \\
\text { (Turan \& Vural, 2018), (Yiğit, 2020), } \\
\text { (Aşlamac1, 2018), (Mevlüt \& Turan, 2013) }\end{array}$ \\
\hline $\begin{array}{l}\text { Tarihsel bağlam açısından İmam } \\
\text { Hatipler }\end{array}$ & $\begin{array}{l}\text { (Emiroğlu \& Uyanık, 2019), (Deniz, 2014), } \\
\text { (Durakbaşa \& Karapehlivan, 2018), (Toker } \\
\text { \& Özcan, 2017), (Duman, 2015) }\end{array}$ \\
\hline $\begin{array}{l}\text { İmam hatip okullarının diğer } \\
\text { paydaşları }\end{array}$ & $\begin{array}{l}\text { (Ankaralı, 2019b), (Aşlamacı \& Eker, } \\
\text { 2017), (Berkant, Tuncer, \& Tanır, 2015) }\end{array}$ \\
\hline
\end{tabular}




\begin{tabular}{|l|l|}
\hline $\begin{array}{l}\text { Sosyo-politik bir olgu olarak imam } \\
\text { hatipliler }\end{array}$ & (Öcal, 1998), (Subaşı, 2004), (Sarpkaya, \\
& 2008), (Bayezit, 2017), (Koyuncu \& \\
& Birekul, 2014), (Batar, 2017), (Coşkun \& \\
& Şentürk, 2010), (Bilecik, 2016), (Çağlar, \\
& 2015), \\
\hline Karşıslaştırmalı çalışmalar & (Kösterioğlu, Çelen, \& Akın Kösterioğlu, \\
& 2019), (N. Özdemir \& Yalçı, 2019), \\
& (Bayram \& Özkamal1, 2019), (E. Suna, \\
& Tanberkan, \& Özer, 2020), (Y1ldız \& Açak, \\
& 2019), (Doğan \& Yuret, 2015), (Mermutlu, \\
& 2008), (Uzun \& Kemerli, 2019), (Tamer, \\
& 2019) \\
\hline Bibliyografik çalışmalar, kitap & (Kaymakcan \& Aşlamac1, 2011), \\
incelemeleri & (Bekiroğlu \& Okan, 2018), \\
\hline &
\end{tabular}

Makalelerin yayınlandığı mecralar dikkate alındığında sırasıyla Talim (13), TürkiyeDin Eğitimi Araştırmaları Dergisi (4), Değerler Eğitimi Dergisi (2), Eskiyeni (2), Journal of International Social Research (2), Kalemname (2), Bilimname (2), İnönü Üniversitesi Eğitim Fakültesi Dergisi (2) dikkat çekmektedir.

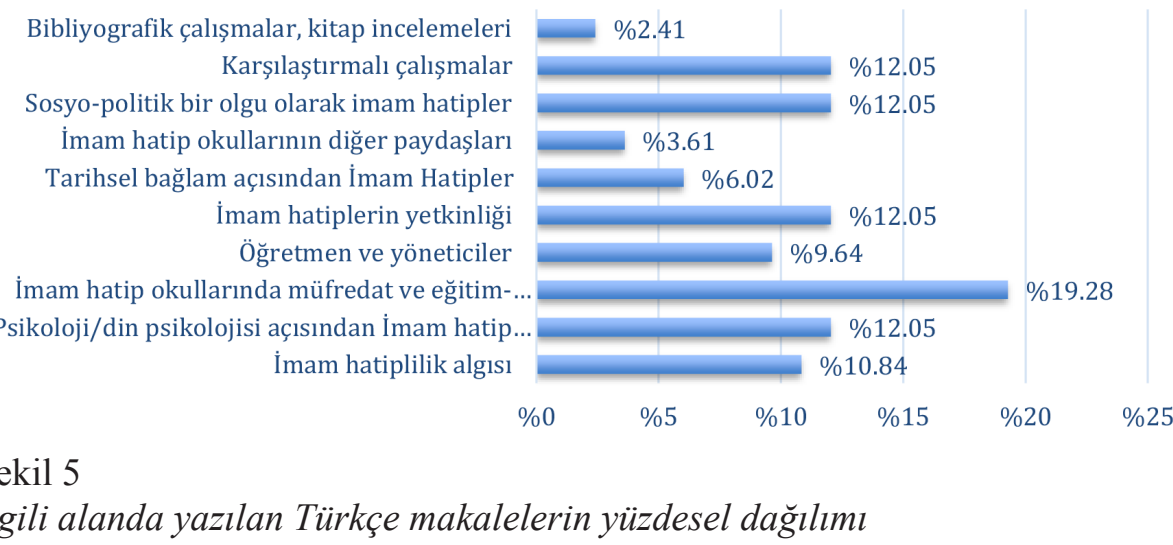


Tablo 3

İmam hatip okullarını konu alan Ingilizce makalelerin alanlarına göre dă̆ılımı

\begin{tabular}{|c|c|}
\hline Alan & $\begin{array}{l}\text { Uluslararası Mecralarda Yayınlanan İlgili } \\
\text { Makaleler }\end{array}$ \\
\hline İmam hatiplilik alg1sı & (Çırak-Kurt \& Kalman, 2019) \\
\hline $\begin{array}{l}\text { Psikoloji/din psikolojisi açısından } \\
\text { İmam hatip öğrencisi }\end{array}$ & (Güven, 2017) \\
\hline $\begin{array}{l}\text { İmam hatip okullarında müfredat ve } \\
\text { öğretim }\end{array}$ & $\begin{array}{l}\text { (Koç \& Baştaş, 2019), (Hasanova, 2018), } \\
\text { (Çınar, 2013) }\end{array}$ \\
\hline Öğretmen ve yöneticiler & $\begin{array}{l}\text { (Kalkan, Aksal, Gazi, Atasoy, \& Dağlı, } \\
\text { 2020) }\end{array}$ \\
\hline \multicolumn{2}{|l|}{ İmam hatiplerin yetkinliği } \\
\hline $\begin{array}{l}\text { Tarihsel bağlam açısından İmam } \\
\text { Hatipler }\end{array}$ & (Ocal, 2007), (Junaedi, 2016) \\
\hline İmam hatip okullarının paydaşları & (Suna et al., 2020), (Koç \& Bastas, 2019) \\
\hline $\begin{array}{l}\text { Sosyo-politik bir olgu olarak imam } \\
\text { hatipler }\end{array}$ & $\begin{array}{l}\text { (Gontijo \& Barbosa, 2020), (Cin, } \\
\text { Karlıdağ-Dennis, \& Temiz, 2020), } \\
\text { (Karlidag-Dennis et al., 2019), (Hendek, } \\
\text { 2019), (Cornell, 2018), (Bayhan \& Gök, } \\
\text { 2017), (Dag, 2018), (Buyruk, 2020), } \\
\text { (Z. Çelik \& Gur, 2013), (Gür, 2016), } \\
\text { (Çakmak, 2009), (Çakmak, 2009), } \\
\text { (Aşlamacı \& Kaymakcan, 2017), (Pak, } \\
\text { 2004a), (Pak, 2004b), (Altinyelken, } \\
\text { Çayır, \& Agirdag, 2015), (M. C. Altıntaş, } \\
\text { 2020), (Rutz, 1999) }\end{array}$ \\
\hline Karşılaştırmalı çalışmalar & $\begin{array}{l}\text { (Gogus \& Saygın, 2019), (Kaya, 2019), } \\
\text { (Önder \& Shamsuddin, 2019), (Dagdemir } \\
\text { \& Tevabil Aka, 2019), (Balyer \& Özcan, } \\
\text { 2020), (Kizilay, Yamak, \& Kavak, 2019) }\end{array}$ \\
\hline $\begin{array}{l}\text { Bibliyografik çalışmalar, kitap } \\
\text { incelemeleri }\end{array}$ & (Güngen, 2013), (Sarfati, 2015) \\
\hline
\end{tabular}




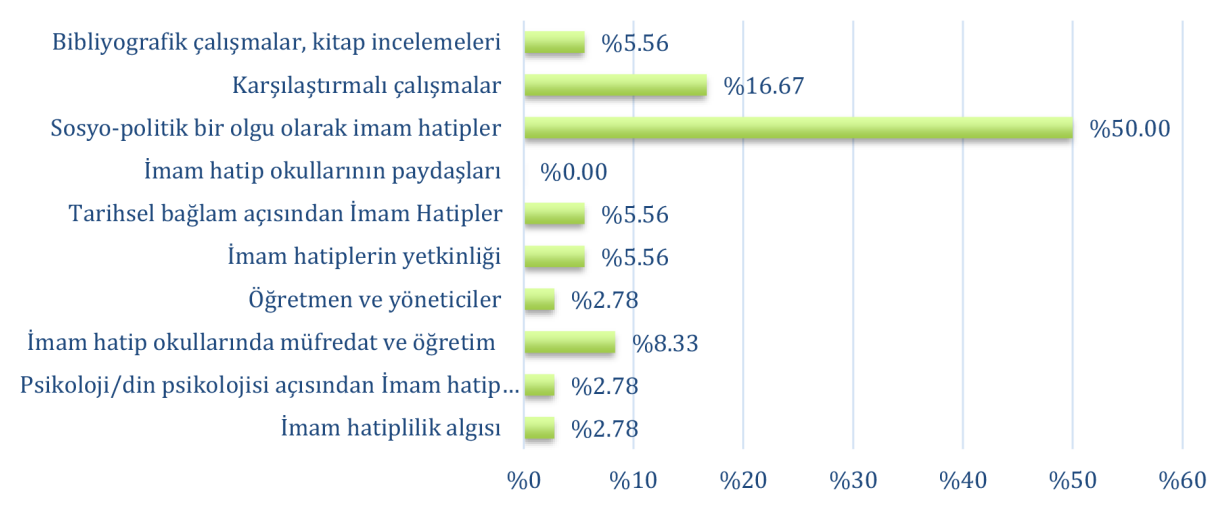

Şekil 6

İlgili alanda yazılan İngilizce makalelerin yüzdesel dă̆ılımı

İmam hatip okullarını konu alan İngilizce makalelerin künyeleri Tablo 3'te verilmiş; bu yayınların konularına göre dağılımı Şekil 6'da detaylı olarak gösterilmiştir. Dağılımın ortaya koyduğu en önemli sonuç, İngilizce alan yazınında imam hatip okullarının ağılıklı olarak sosyo-politik bir olgu (\%50) olarak ele alınmış olmasıdır. Bu kategorideki makaleler detaylı olarak incelendiğinde imam hatip okullarının daha çok ideolojik bir tartı̧̧manın ve ülkenin Doğu-Batı arasındaki yöneliminin bir parçası olarak ele alındığı görülmektedir. İkinci sırada da imam hatip okullarını diğer eğitim kurumlarıyla kıyaslayan çalışmalar (\%16.67) yer almaktadır. Öte yandan, imam hatip okullarının paydaşlarına ilişkin hiçbir çalışmaya rastlanmamıştır. Bu okulların asli unsurları olan yönetici, öğretmen ve öğrenciler de çalışmalarda oldukça az yer bulmuştur. İmam hatiplilik algısı, din psikolojisi açısından imam hatip okulları, öğretmen ve yöneticilere başlıklarındaki çalışmaların oranı sadece \%2.78'dir.

\section{Bazı Çalışmalara İlişkin Mülahazalar}

Bu kısımda yukarıda on kategoride sunulan çalışmalardan önemli görülen ve temsil niteliğinde olanlar daha detaylı bir incelemeye tabi tutulacaktır.

İmam hatip okulları ile doğrudan ilintili tezler arasında yer alan en dikkat çekici çalışmalardan biri 2014'te "Pakistan Medreselerine Model Olarak İmam Hatip Liseleri" (Aşlamacı, 2014) başlığıyla yapılmış olan çalışmadır. Bu çalışmada Pakistan medreseleri ile imam hatip okullarının benzerlik ve farklılıkları tartışılmış, iki modelin birbirine entegre edilip edilemeyeceği sorusuna cevap aranmıştır. Aşlamacı'ya göre Pakistan medreseleri ve Türk imam hatip okulları ortak bir dini eğitim hedefi paylaşmalarına rağmen entegre edilemezler. İmam hatip okulları \% 40'1 din dersleri, \% 60'1 ise seküler bir eğitim içeren müfredatıyla daha çok bilimsel bir çaba içerisindedir. Pakistan medreselerinde ise müfredat kapsamında her ne kadar pozitif bilimlere yer 
verilse de imam hatip okullarına kıyasla dini eğitim kaygısı ve hassasiyetinin daha baskın olduğunu söylemek yanlış olmayacaktır.

Bir diğer önemli çalışma 2016'da 'Hegemonya ve Karş1-Hegemonya İnşasında Eğitimin Rolü: Köy Enstitüleri ve İmam Hatip Okulları Üzerinden Karşılaştırmalı Bir Analiz" (Can, 2017) başlığıyla yapılmış çalışmadır. Bu çalışmada, temel alınan kuramsal çerçeve üzerinden, Türkiye'de köy enstitüleri ve imam hatip okulları pratiklerinin karşılaştırmalı bir analizinin yürütülmesi amaçlanmıştır. Sonuç olarak bu iki eğitim pratiğinin, Osmanlı'dan günümüze hâkim iki grup [Batıc1/İslamcı Modernleş(tir) meciler] arasında süregiden bir hegemonya mücadelesinin yansıması olduğu kanısına ulaşılmaktadır.

Bunların dışında meslek dersleri öğretiminde öğretmenin rolünü Sivas ilindeki imam hatipler özelinde ele alan çalışma (Mücahit, 2016) ve imam hatip lisesi öğrencilerinin Arapça konusundaki yeterliliklerini Isparta örneğinde ele alan doktora tezi (Yaman, 2016) burada zikredilmesi gereken iki saha çalışmasıdır.

Türk milli eğitim sistemi içerisinde yer almakla birlikte konumu ve işlevleri hep tartışma konusu olan imam hatip okullarına yönelik hem kurum içinde hem de kurum dışında oluşan algı önemli bir araştırma konusudur.

$\mathrm{Bu}$ bağlamda ele alacağımız ilk çalışma öğrencilerin imam hatip okullarını tercih etmelerinde rol oynayan etkenlerin neler olduğuna yönelik bir çalışmadır. Özyiğit (2018) tarafından yürütülen araştırma sonucunda, imam hatip okullarının tercihinde sırasıyla aile isteği, okul idaresi ve öğretmenlerin olumlu yaklaşımları, bir sonraki eğitim seviyesine daha iyi hazırlanma ve daha iyi okullar kazanma inancının etkili olduğu tespit edilmiştir. Öğrencilerin tercihlerinde cinsiyet ve gelir durumunun istatistiksel açıdan anlamlı bir etkisi olmadığı da görülmüştür. Ayrıca, bu saha çalışmasında ögrencilerin imam hatip okulları hakkında genel anlamda müspet bir algısı olduğu sonucuna ulaşılmıştır.

$\mathrm{Bu}$ minvalde yapılan bir diğer çalışma ise imam hatip öğrencilerinin okul mensubiyetlerine ilişkindir. Terlemez'e göre (2019) imam hatip okulları diğer okullara nazaran pek çok açıdan öğrencilerinin beklentilerini daha üst seviyede karşılamaktadır. Müfredat, fiziksel koşullar, sosyo-kültürel imkânlar öğrencilerin memnun olduğu boyutlar arasında sıralanabilir. Öğrencilerin okullarını algılama biçimleri ise okulda edindikleri belli kazanımlarla doğrudan ilişkilidir. Bu kazanımlar onlara toplumsal ve dini alanda çeşitli rol ve sorumluluklar yüklemekte, sorumluluk, dindarlık ve liderlik bilinci aşılamaktadır. Öğrenciler sosyal çevrelerinde zaman zaman ön yargı ve küçümseme davranışlarına da muhatap olmaktadırlar.

Acar (2014) tarafından 2014 yılında Bingöl'de 364 imam hatip öğrencisi üzerinden yürütülen çalışmada öğrencilerin dini sorumluluk algıları dört bağımsız değişken özelinde incelenmiştir.. Sonuçlar göstermektedir ki; öğrencinin okul tercihindeki aktif rolü ve okulun türü dini sorumluluk düzeyinde farklılaşmaya yol açarken, cinsiyet ve sınıf düzeyi anlamlı bir fark yaratmamaktadır. Benzer bir araştırmada imam hatip 
okulu öğrencilerinin dini tutum ve okul aidiyet düzeyleri arasında pozitif yönlü anlamlı bir ilişki olduğu ve bu ilişki düzeyinin il, cinsiyet, sınıf, imam hatip tercih sebebi ve üniversitede okumak istedikleri alan değişkenleri açısından farklılık gösterdiği tespit edilmiştir (Aşlamacı \& Eker, 2016).

İmam hatip okullarını tercih eden öğrencilerin tercihlerindeki etkenleri detaylı bir incelemeye tabi tutan Çetin'in (2017) yapmış olduğu saha çalışmasının sonuçları da oldukça ilgi çekicidir. Araştırmada sonucunda öncelikle öğrencilerin okullarına karşı tutum düzeyleri ölçülmüş ve orta seviyede olduğu görülmüştür. Öğrencilerin okula karşı tutumları ile ailesel faktörler (anne-babanın sağlık durumu, medeni durumu, ailenin gelir ve çalışma durumu) arasında bir ilişki tespit edilememiştir. Ayrıca öğrencinin cinsiyet ya da kitap okuma alışkanlığı gibi özelliklerinin de okula karşı tutumlarını etkilemediği gözlemlenmiştir. Okula yönelik tutumu anlamlı bir biçimde etkileyen tek değişken öğrencinin okulu bireysel olarak tercih etme durumu olmuştur.

Araştırmacıların dikkatini çeken bir diğer husus ise dini bir eğitim vermeyi amaçlayan imam hatip okullarında yetişen öğrencilerin Allah ve Peygamber tasavvurlarının nasıl şekillendiği sorusudur. Bu soruya cevap niteliğinde olan iki tez çalışmasını incelediğimizde şunları tespit etmekteyiz: Çalışmalardan biri (Taluk, 2014), imam hatip öğrencilerinin Allah tasavvuruna yönelik yapılmış olan bir saha çalışmasıdır. Söz konusu çalışma bize tümel bir bilgi vermez, lakin incelenen fenomeni anlamak için bir 1 şık tutma çabasıdır. Örneklemini 14-15 yaşlarındaki gençlerin oluşturduğu bu çalışmada katılımcıların Allah tasavvurları belirli değişkenlere göre farklılık göstermektedir. Katılımcıların \%57'sinin “Allah'ın varliğına kesin olarak inanlyor ve hiçbir şüphe taşımıyorum.” ibaresini tercih etmesi, öğrencilerin yarısından fazlasının Allah'ın varlığı konusunda inkârcı ya da şüpheci bir zihne sahip olmadıklarını göstermektedir. Bunun yanında geri kalan \%43'lük kesim bu ibareyi kullanmamaktadır. Bu da bizi bazı öğrencilerin zihinlerindeki temel dini kaygı ve soruların aile ve öğretmenler tarafından yeterince izale edilemediği sonucuna götürmektedir. Bu eksiklik ve oluşan Allah algıSı öğrencilerin ibadet etme oranlarına ve yaşam tarzlarına yansımaktadır. Mevzubahis çalışma bize, İmam hatip liselerindeki müfredatın inanç ekseni boyutuyla yeniden düzenlenmesi gerektiğini göstermektedir.

İkinci çalışma ise imam hatip okulu öğrencilerinin peygamber tasavvurlarının keyfiyetine ilişkindir. Yanmaz'ın (2013) tezinin ulaştığı sonucu şu şekilde özetlemek mümkündür. İmam hatip liselerinde verilen tutucu ve eleştirel olmayan dinî eğitim; öğrencilerin inanç sistemlerini doğrudan etkilemektedir. Bu yaklaşım imam hatip öğrencilerinin büyük bir çoğunluğunu aşırı yüceltmeci bir peygamber tasavvuruna yöneltmektedir. Öğrencilerin çoğunluğunun nazarında Hz. Peygamber hata yapmayan, mucizelerle donatılmış insanüstü bir varlıktır. Ayrıca, Peygamber tasavvuru ile ailenin gelir seviyesi ve öğrencinin namaz kılma sıklığı arasında da anlamlı bir ilişki mevcuttur. Gelir seviyesi yükseldikçe yüceltmeci Peygamber tasavvuru yerine beşer bir Peygamber tasavvuruna bırakmaktadır. İmam hatip öğrencilerinin sosyal hayatta üstlendiği din eksenli roller göz önüne alındığında, zihinlerindeki Peygamber tasavvurunun toplumdaki dini yaşayışı etkileme gücü de ortaya çıkacaktır. 
Değinmek istediğimiz bir diğer nokta ise imam hatip öğrencilerinin mesleki yeterlilik algılarıdır. Toplumda din önderleri olarak görülen bu öğrencilerin aldıkları eğitimin gereğini icrada ne denli yeterli olduğu sorusuna odaklanan pek çok çalışma yapılmıştır. Mevzubahis tezlerin daha çok saha çalışması olmaları hasebiyle bazı noktalarda farklı sonuçlar elde edilmiş olmasına rağmen, çalışmaların hemen hemen hepsinde karşımıza çıkan ortak değerlendirmeler de mevcuttur. Burada değişik görüşlerden çok imam hatipler hakkında ulaşılan genel kanaat ve beklentileri beş ana başlıkta sıralamanın daha uygun ve yararlı olacağı kanaatindeyiz.

- Öncelikle, imam hatip okulu öğrencileri aldıkları dini eğitimden dolayı topluma örnek bireyler olmaları gerektiğinin farkında ve toplum tarafından bu şekilde algılandıklarının bilincindedirler.

- İmam hatip okulu öğrencilerinin çoğunluğu okula başladıktan sonra dindarlık düzeylerinin arttığını, davranışlarında olumlu yönde değişiklikler yaşadıklarını ifade etmişlerdir.

- İmam hatip okullarındaki ders yükünün diğer okullara göre ağır olması öğrenci portföyünün bu ağırlığı kaldırabilecek bireylerden oluşmasını gerektirmekte, düşük puanlı öğrencilerin bu okulları tercih etmeleri hem öğrencilerin özgüvenini hem de din eğitimi kalitesini kötü yönde etkilemektedir.

- Öğrenciler söz konusu meslek derslerinin ağırlığından şikâyet etmekle birlikte, bu dersleri sevdiklerini de dile getirmektedir. Lakin derslerin güncel sorunlara cevap verip vermediği konusunda öğrenciler arasında fikir birliği yoktur.

- İmam hatip okulu öğrencileri, aldıkları eğitimin din görevlisi olarak çalışmaları için yeterli olmadığını düşünmektedirler. Bununla birlikte okulda aldıkları eğitime ek olarak din eğitimi alan öğrenciler, kendilerini daha yeterli gördüklerini ifade etmişlerdir. İmam hatip okullarının kuruluş amaçlarından biri olan din görevlisi yetiştirme hedefine ulaşamıyor olması kayda değerdir (Özyurt, 2015).

Mevcut hükümetin yaptığı değişiklikle imam hatip okullarında katsayı probleminin kaldırılması ve akabinde bu okulların sayısının artırılması öğrencilerin psikoloji, davranış ve tutumlarında değişikliklere sebep olmuştur. Bu değişikliklere odaklanmış bir tez çalışması son derece ilgi çekicidir (Çelik, 2016). Bu çalışmadan çıkardığımız belli başlı sonuçlar şunlardır:

- Öncelikli soru, katsayı uygulamasının kaldırılmasının, İmam hatip liselerinin başarılı öğrenciler tarafından tercih edilmesinde olumlu yönde bir etkiye sebep olup olmadığıdır. Bu soruya cevap vermek oldukça zor olmakla beraber imam hatip okul ve öğrenci sayısının plansız bir şekilde artması nicel bir 
başarıdır. İstisnai durumlar dışında aynı başarıyı nitelik bakımından söylemek maalesef mümkün görünmemektedir. Dolayısıyla katsayının kaldırılması başarılı öğrencilerin imam hatip okullarını tercih etmesinde müspet bir etki yapmamıştır.

- İmam hatip lisesi öğrencilerinin önemli bir kısmı okullarına güçlü bir aidiyet duygusu beslemekte ve büyük bir çoğunluğu toplum içinde 'İmam Hatipli Olma' kimliğini ifade edebilmektedir. Bu aidiyet hissi ilahiyat dışı bir bölüm tercih etmelerinin önünde bir engel teşkil etmemektedir. Nitekim katsayı probleminin kaldırılması ile öğrencilerin büyük kısmı üniversite tercihi noktasında mesleki alanlarının dışındaki bölümleri de düşünmeye başlamıştır (Çelik, 2016).

Bu kısımda bahsetmek istediğimiz son çalışma, küreselleşen ve hazları yücelten bir dünyada dini eğitim alan imam hatip öğrencilerinin nerede durduğunu araştıran, öğrencilerin tutum ve davranışlarını güncel olan bağlamında değerlendiren bir tez çalışmasıdır. Endüstri toplumundan bilgi ve ağ toplumuna evrilen post-modern zamanlarda sosyal medya ve hesaplar, şahsi profil ve paylaşımlar günlük yaşamımızın vazgeçilmezleri arasına girmiştir. Çalışmada neredeyse herkesi içine alan bu yeni sistemin imam hatip lisesi öğrencilerini de çevrelediği ve toplumsal ve dini değerlerinin zayıflamasına sebep olduğu vurgulanmaktadır. Dindarlık derecesi öğrenciden öğrenciye değişiklik göstermektedir. Popüler kültürün pençesinde olan bu öğrencilerden kimisi bu kültürün getirdiği birçok şeyi tüketip hazzına varırken; kimisi de bu dünyadan uzak kalamasa da dini vecibelerini yerine getirmeye çalışmaktadır. Toplumun farklı kesimlerinin iç içe olduğu imam hatip okullarında, küreselleşmeye rağmen dinin temellerini ve prensiplerini önemseyen ve önceleyen bir anlayış kararlılıkla varlığını sürdürmektedir (Aksu, 2018).

Çoşkun ve Şentürk (2010) araştırmalarında imam hatip okulu öğrencilerinin hâkim dünya görüşlerini ve son dönemde bu dünya görüşünün geçirdiği değişimleri keşfetmeye çalışmışlardır. Araştırma kapsamında katılımc1 öğrencilerin göstermiş oldukları tutumların zamanla değiştiği sonucuna ulaşılmıştır. Önceleri radikal/gelenekçi bir tutum sergileyen öğrencilerin zamanla muhafazakâr/modernist bir çizgiye kaydıkları görülmektedir. Bu değişimin Türkiye'de son yıllarda gerçekleşen ekonomik, siyasal ve kültürel değişim ve dönüşümlerden kaynaklandığı öne sürülmektedir

İmam hatip okullarının müfredatına yönelik çalışmalar daha çok meslek derslerini (Kur'an, Hadis, Tefsir, Arapça, Dini Musiki, Karşılaştırmalı Dinler Tarihi ve İslam Mezhepleri Tarihi) ele almışlardır.

Yüksel (2016) tarafından yürütülen çalışmada Kur'an eğitiminin önündeki zorlukları tespit etmek, yeni metotlar geliştirmek ve teknik imkânlardan yararlanarak başarıyı artıracak yöntemler sunmak hedeflenmiştir. Çalışmada hem öğretmenlere hem de öğrencilere yönelik hususlar incelenmiştir. Böylece çift yönlü bir yaklaşım ile daha yerinde tespitler ve çözüm önerileri ortaya konmuştur. 
İçine doğduğumuz ve çevremizde uygulamalarına şahit olduğumuz dinin gerekleri gibi mensubu olduğumuz mezhebin de gereklerini ilk aşamada yakın çevremizden öğrenmekteyiz. Bu durum zaman zaman diğer mezheplere yönelik ötekileştirici bir bakış açısı oluşturmaktadır. Bu nedenle mezheplerin din değil sadece dinin bir yorumu olduğu bilgisinin toplumsal algıya yerleştirilmesi gerekmektedir. Bu çabanın mekanı din eğitimi verilen imam hatip okulları olmalıdır. İmam hatip müfredatı içerisinde yerini alan İslam Mezhepleri Tarihi dersi, bu bilginin evvela öğrencilere ve öğrenciler üzerinden topluma taşınması için bir araç olarak düşünülmelidir. Literatürde bu dersin müfredatının değerlendirildiği ve yeniden iyileştirmeye yönelik katkıların yapıldığı yapıcı çalışmalar da yer almaktadır (Kubat, 2019).

İmam hatip okullarında verilen derslerden bir diğeri de dini musiki dersleridir. Şüphe yok ki, dini musiki din görevlisi olacak mezunların meslek hayatı içerisinde ihtiyaç duyacakları bir alandır. Musiki formlarını güzel icra edebilme ve eğitimli ses, dini musiki dersi ile kazandırılmaya çalışılmaktadır. Tarihsel olarak ilk defa 1985 yılında okutulmaya başlanan bu ders, literatürde çeşitli açılardan ele alınıp değerlendirilmiştir. Mevzubahis dersin dini musiki ile ilgili konuların hepsini kapsamaması ve ders süresinin yetersiz oluşu gibi çeşitli eleştirel sonuçlara ulaşılmıştır. Sevinç (2017) tarafindan yürütülen çalışmada da imam hatip okullarındaki dini musiki dersinin tarihsel süreci incelenmiş, ardından eski ve yeni öğretim programları çeşitli yönlerden ele alınmıştır.

İmam hatip okullarında öğrencilerin dini hassasiyeti önemseyen ve önceleyen bir anlayışla yetişmesinde nitelikli öğretmen ve idarecilerin rolü büyüktür. İmam hatip okullarında görev yapan öğretmenlerin sahip oldukları vizyona ilişkin yapılan çeşitli çalışmalar da (Uçar, Polat, \& Altun, 2016) tezimizi doğrular niteliktedir. Bu çalışmada imam hatip okullarında görev yapmakta olan meslek dersleri öğretmenlerinin "İmam Hatipli Vizyonu"nun ne olduğu, ortaya çıkan vizyonların ne gibi ortak özelliklere sahip olduğu belirlenmeye çalışılmıştır.

Bunun yanında, imam hatip okullarında görev yapan öğretmenlerin örgütsel kimlik algılarının düzeylerini belirlemek ve bazı değişkenlere göre durumunu ortaya koymaya çalışan araştırmalar da (Arslan, 2018) yapılmıştır. Arslan (2018) tarafından yapılan bu çalışmada araştırmaya katılan öğretmenlerin örgütsel kimlik düzeylerinin mezun olunan fakülte değişkeninden anlamlı bir biçimde etkilendiği sonucuna ulaşılmıştır.

Literatürde farklı kurumlarda görev alan öğretmenlerin sorunlarına ilişkin çeşitli çalışmalar mevcuttur. Bu amaçla yapılan-araştırmalardan biri de (Baltacı, 2019c) imam hatip okullarında görev yapan öğretmenlerin mesleki sorunlarına yöneliktir. Elde edilen verilere göre öğretmenlerin sorun olarak ifade ettiği temaları şu şekilde sıralayabiliriz; din eğitimine ilişkin sorunlar, öğretmen kaynaklı sorunlar, öğrenci kaynaklı sorunlar, okul yöneticilerinden kaynaklanan sorunlar ve üst yönetim kaynaklı sorunlar.

İmam hatip okulu müfredatının dizaynı açısından önem arz eden bir diğer husus ise, 12. sinıflarda okutulan meslek derslerinin ilahiyat dışında lisans eğitimi almayı hedefleyen öğrenciler açısından oluşturduğu zorluktur. Öğrenciler özellikle son sınıfta aldıkları meslek derslerini teorik, sıkıcı ve ağır bulmaktadır. Bu öğrenciler imam 
hatip okulu meslek dersleri içeriklerinin kendilerine hitap etmediğini düşünmektedir. Öğrenciler, ders kitaplarının faydalı ve ilgi çekici olmadığını ancak öğretmenlerin anlatma biçiminin dersleri ilgi çekici hale getirebileceğini düşünmektedirler. Ayrıca, son sınıfta sınava hazırlanma süreci içerisinde meslek derslerine yeterince vakit ayıramadıkları için bu derslerin 9. ve 10. Sınıfa kaydırılmasını teklif etmektedirler. Bununla birlikte ortaya koydukları eleştirilerin derslere önem vermemekten kaynaklı olmadığını söylemektedirler (Kaya, 2018).

Bu kısımda inceleyeceğimiz son konu başlı̆̆ imam hatip okullarının tarihçesine ilişkin yazın olacaktır. Türkiye'de dinin ve dini eğitimin; gelişme, ilerleme ve modernleşmenin önünde engel teşkil ettiğini savunan seküler anlayışa karşılık, dinine bağlı ve dini eğitimi savunan muhafazakâr yaklaşım her zaman varlığını korumuştur (Toker \& Özcan, 2017). Cumhuriyetin ilanıyla birlikte eğitim sistemi laik bir anlayış üzerine kurulmuş olup din konusunda sürekli bir gerilim söz konusu olmuştur. Tevhid-i Tedrisat ile birlikte din eğitimini tekeline alan devlet toplumun muhafazakâr kesimlerinden gizli/açık tepki almıştır. Zamanla dini eğitimin yasaklanmasının olumsuz sonuçlarını engellemek adına yine devlet eliyle dini eğitim veren imam hatip okulları açılmıştır (Deniz, 2014). İmam hatip okullarının kuruluş ve gelişme süreçleri ve bu süreçleri etkileyen faktörler de çeşitli araştırmalara konu olmuştur (Çınar, 2013).

\section{Sonuç}

İmam hatiplerin tarihinin Türkiye Cumhuriyeti tarihinden daha eskilere dayandığı; 1912 yılının imam hatip okullarının temelinin atıldığı yıl olduğu söylenebilir. Osmanlı Devleti'nin vaiz yetiştirmek amacıyla 28 Aralık 1912'de kurduğu Medresetü'l-Vaizin ile imam ve hatip yetiştirmek üzere 1913'te açılan Medresetü'l-Eimme ve'l-Huteba, imam hatiplerin ilk örneklerini oluşturmaktadır. Bu iki medresenin daha sonra 1919'de Medresetü'l İrşad adıyla birleştirildiği görülmektedir. Daha sonra TBMM kararıyla 8 Mayıs 1921'de Bilim Medreseleri Kanunnamesi çıkarılmıştır. Bu kanunname ile imam hatip liselerinin ilk örneği olarak kabul edilen okulların müfredatı bugünkü müfredata benzer bir şekilde düzenlemiştir. Bu okullar, kısa bir süre geçtikten sonra 3 Mart 1924'te çıkarılan Tevhid-i Tedrisat kanunu gereğince kapatılmıştır.

Ardından çıkarılan bir kanunla ilk kez imam hatip ismi kullanılmaya başlanmıştır. Yeni kanun din adamı yetiştirmek üzere imam hatip mektepleri açılmasını öngörmüştür. $\mathrm{Bu}$ mektepler ise çok geçmeden çeşitli sebepler ileri sürülerek 1932'de tamamen kapatılmıştır. Bu okulların kapatılmasıyla birlikte devlet eliyle kontrol altına alınıp yönetilmek istenen din eğitimi alanı halka büyük bir boşluk ve ihtiyaç olarak yansımıştır. Halkın durumu 30 yıllık aradan sonra yeniden gözetilmiş ve bu okullar tekrar açılmıştır. Tarihinde sürekli gel-gitler yaşamış ve polemiklere konu olmuş imam hatip okulları geleneği bozmayarak 28 Şubat sürecinde de hedef olmuştur. Bu süreçte başörtü yasağı ve katsayı gibi engellere maruz kalan imam hatip okullarının ortaokul kısımları kapatılmış; 2011 yılında katsayı problemi ortadan kalkarken 2012-2013 eğitim öğretim döneminde imam hatiplerin orta kısmı tekrardan açılmıştır. 
Siyasi anlamda ideolojik tepkilerin hedefi olan imam hatipler özellikle 2011 y1lı sonrasında akademik alanda da ele alınan ve incelenen konulardan biri olmuştur. Yapmış olduğumuz bu çalışma literatürde yer alan imam hatipleri konu edinmiş çalışmaları bütüncül bir bakış açısıyla değerlendirmeyi hedeflemektedir. Çalışma kapsamında 2011 sonrası yayımlanmış çok sayıda akademik çalışma incelenmiş ve bazı sonuçlara ulaşılmıştır. Ulaşılan bu sonuçların mutlak çıkarımlar olmadığı unutulmamalıdır. İmam hatiplerle ilgili değişmez ve sarsılmaz bilgiler vermek bu çalışmanın ulaşmak istediği hedefler arasında yer almamaktadır. Çalışmamız, imam hatip okullarıyla ilgili olarak oluşan bilgi kirliliği ve soru işaretlerinin ortadan kalkmasına yönelik olarak yapılan akademik çalışmaları kapsamlı bir biçimde ortaya koyma amacı taşımaktadır.

1989-2020 yılları arasında tamamlanmış imam hatip okullarını konu alan tez çalışmaları toplamda 103 'dir. Bu çalışmaların 89'ü yüksek lisans tezi iken, 14'ü doktora tezidir. 2009 yılında imam hatip okullarındaki katsayı problemi kaldırıldıktan sonra bu okulları odağına alan lisansüstü çalışmalarda ciddi bir artış söz konusudur. İmam hatiplerle ilgili yapılmış doktora çalışmaların en yoğun olduğu zaman dilimi ise 20132016 yıllarıdır. Sonraki yıllarda da bu ilgi sürmüştür.

1995-2020 yılları arasında imam hatipler üzerine yazılmış makale sayısı 116'dır. Bu makalelerin 79'u Türkçe, 37'si İngilizce makalelerdir. Türkçe makalelerin rağbet görmeye başladığ y yıl da tahmin edileceği gibi 2011'dir. İngilizce çalışmalar ise 2015 yılından sonra ivme kazanmıştır.

Çalışmada Kaymakcan ve Aşlamacı'nın (2011) yazın incelemesi de dikkate alınarak, özellikle 2011 yılından sonra yayınlanan eserler, kitap/tez, Türkçe makaleler ve uluslararası mecralarda yayınlanmış İngilizce makaleler derinlemesine incelenmiş̧ir. İmam hatipleri konu alan çalışmalar incelendiğine okulların çok farklı veçheleri ile ele alındıkları sonucuna ulaşılmışıı. Bu nedenle bu çalışma incelenen eserleri konularına göre on ana başlık altında sınıflandırmıştır.

2011-2020 yılları arasında yayımlanan 219 çalışmanın konuları itibariyle dağılımına bakıldığında, imam hatip okullarının akademide en çok sosyo-politik bir öğe olarak incelendiği görülmüştür. Çalışmaların neredeyse \%20'si bu başlık altında sınıflandırılabilir. İkinci ve üçüncü sırada \%15'e yaklaşan oranlarıyla imam hatip okullarındaki müfredat ve imam hatiplilik algısını inceleyen çalışmalar yer almaktadır. Sıralamanın sonunda yer alan başlıklar ise sırasıyla tarihsel bağlamda imam hatipler (\%5.44), imam hatip okullarının paydaşları (\%4.08) ve literatür taramaları (\%2.72) olmuştur.

Bunun yanında yazılan kitap ve tezlerin çoğu (\%29.27) imam hatiplilik algısı üzerinedir. Bunun yanında müfredata yönelik çalışmalar da geniş yer tutmaktadır. Dikkat çekici bir başka nokta okulların diğer paydaşlarına ve sosyo-politik yönüne dair kitap ve tezlerin sayısı yetersizdir. 
Türkçe makaleler incelendiğinde; özellikle son üç yılda (2018, 2019 ve 2020) imam hatip okullarına yönelik yayınlarda ciddi bir artış olduğu görülmektedir. Makalelerin yüzdesel dağılımı dikkate alındığında nispeten dengeli bir dağılım görülmektedir.

İmam hatip okullarını konu alan İngilizce makalelerin dağılımının ortaya koyduğu en önemli sonuç, İngilizce alan yazınında imam hatip okullarının ağırlıklı olarak sosyopolitik bir olgu (\%50) olarak ele alınmış olmasıdır. İkinci sırada da benzer biçimde imam hatip okullarını diğer eğitim kurumlarıyla kıyaslayan çalışmalar (\%16.67) yer almaktadır. Öte yandan, imam hatip okullarının öğretmen, yönetici gibi asli unsurlarına ve veli, sivil toplum, okul aile birliği dernekleri gibi paydaşlarına ilişkin çok az çalışma tespit edilmiştir.

Çalışma kapsamında imam hatip okulları ile doğrudan ve dolaylı ilintili önce çıkan bazı çalışmalara daha detaylı değinilmiştir. Bu detaylı incelemelerden elde ettiğimiz sonuçlar şu şekildedir:

1. İmam hatip öğrencilerinin bu okulları tercihlerinde ailelerinin istekleri ve okul, öğretmen ve idarecilerinin pozitif tutumları etkili rol oynamaktadır. Öğrencilerin okullarına ilişkin tutumları genel anlamda olumludur. Cinsiyet ve ailenin gelir durumunun tercihlerde istatistiksel açıdan anlamlı bir etkisi tespit edilememiştir.

2. İmam hatip okulları ögrencilerinin dini tutum ve okul aidiyet düzeyleri arasında pozitif yönlü anlamlı bir ilişki olduğu ve bu ilişkinin il, cinsiyet, sınıf, imam hatip tercih sebebi ve üniversitede okumak istenilen alan vb. değişkenler açısından farklılık gösterdiği tespit edilmiştir.

3. İmam hatip öğrencilerinin okulda edindikleri deneyimler ile imam hatipli kimliklerine katkı sağladıkları görülmüştür. Bu katkı toplumsal düzeyde insanlara rol model olup, belli meselelerde liderlik etme şeklinde kendini göstermiştir.

4. İmam hatip öğrencileri Allah tasavvuru konusunda hemen hemen aynı düşünceye sahipken, peygamber tasavvuru konusunda karışı bir düşünce yapısına sahiptirler. Yanlış ve hatalı tasavvurların eğitimde gösterilen zafiyetlerden kaynaklandığı düşünülmektedir.

1. İmam hatip okullarındaki meslek derslerinin ağırlığından şikâyet eden öğrenciler ilahiyat dişında alanlarda ihtisas yapmak isteyen öğrencilerdir. Öğrenciler, ders kitaplarının faydalı ve ilgi çekici olmadığını bulmamakta, 12 . sınıf meslek derslerinin 9. ve 10. sınıflara kaydırılmasını teklif etmektedirler. 
2. Katsayı problemi kaldırıldıktan sonra bu okulları başarılı öğrencilerin tercih edip etmediği sorusuna kesin bir yanıt vermek mümkün değildir. Lakin imam hatip okullarına rağbet edilmesi nicel anlamda bir başarının sonucudur.

3. İmam hatip okullarında görev yapan öğretmenler ise mesleki yeterliliğe sahip ve gelişime açık, öğrenme motivasyonu yüksek, araştıran, sorgulayan, eleştiren, çalışkan, güncel, ehl-i sünnet çizgisinde ama mezhep taassubu olmayan, farklı inançlara saygılı bir öğrenci arzuladıklarını ifade etmişlerdir.

4. Araştırmalara göre imam hatip öğrencilerinin dünya görüşü zamanla radikal/gelenekçi bir tutumdan muhafazakâr/modernist bir tutuma evrilmiştir.

\section{Yapılacak yeni Çalışmalara Yönelik Bazı Tavsiyeler}

Bu çalışma kapsamında değindiğimiz çalışmalar imam hatiplerle ilgili akademik yayın yapmak isteyenler için rehber olacak niteliktedir. Bunun yanında çalışılması halinde literatüre büyük katkı sağlayacağını düşündüğümüz bazı konular da bulunmaktadır.

Mesela, imam hatip ortaokulundan mezun olan başarılı öğrencilerin lise için imam hatip liselerini tercih edip etmediği sorusunu cevaplamak imam hatip okullarına ilişkin sağlıklı bir değerlendirme yapılması açısından önemlidir. İmam hatip lisesine devam eden öğrencilerin bu kararlarının temel öncülleri nelerdir? İmam hatip liselerinde başarı sağlayacaklarına neden olan düşünce neye dayanmaktadır? Bunun yanında imam hatip okullarından diğer liselere geçiş yapan öğrencilerin tercihlerinin müspet ya da menfi sonuçları neler olmuştur? Bu ve benzeri soruları cevaplayabilecek çalışmalara ihtiyaç olduğu aşikârdır.

Öte yandan, küreselleşen dünyada imam hatip öğrencilerinin konumu da akademik bir çalışma kapsamında incelenebilir. Öğrencilerin ilgileri, zamanlarını nasıl geçirdikleri, depresif öğrenci profilinin hâkim olduğu günümüzde psikolojik iyi oluşları, boş zamanlarını hangi aktivitelerle geçirdikleri cevaplanması halinde imam hatiplere ilişkin bilgimizi zenginleştirecek ve iyileştirme önerilerine yol açacak sorulardır.

Bir diğer önemli soru imam hatip öğrencilerinin aldıkları dini eğitim güncel anlatım teknikleri ile daha işlevli ve verimli hale gelmiş midir? Hayat tarzlarının temelinde maddi mi manevi mi kaygılar yatmaktadır? Sekülerizmin yansımaları tam olarak hangi alanlarla temayüz etmiştir?

Ayrıca imam hatiplerin başarılı veya başarısız olduğu iddialarına cevap verecek nicel verili bir çalışmaya ihtiyaç olduğu kanaatindeyiz. Bu öğrenciler için başarı tanımı nedir? Başarılı olarak tanımladıkları kimseler kimlerdir? İmam hatip öğrencilerinin kendine örnek aldığı kişiler kimlerdir? Genelde okudukları kitap türü nedir? Dinledikleri müzik türü nedir? İzledikleri film türü nedir? soruları yöneltilerek günümüz imam hatip öğrencilerine 1şık tutulabilir. 
Uluslararası alanda resmi bir eğitim politikasının parçası olan bu okulların amacını ve toplumdaki rolünü, Türkiye dışında aynı statüde eğitim veren okullarla benzerlik ve farklılıklarını politik tartışmalar dışında sosyolojik bir olgu olarak ele alacak çalışmalara ciddi ihtiyaç vardır.

\section{Kaynakça}

Acar, M. C. (2014). İmam-Hatip Lisesi Öğrencilerinin Dinî Sorumluluk Düzeylerinin İncelenmesi: Bingöl Örneği. Bingöl Üniversitesi İlahiyat Fakültesi Dergisi, 2(4), 151-161.

Ağçoban, S. (2018). İmam Hatip Liselerinde Okutulan Ders Kitaplarının Bireycilik ve Kolektivizm Açısından İncelenmesi. Talim: Journal of Education in Muslim Societies and Communities, 2(1), 53-83.

Akarsu, S. (2019). İMAM HATIP ORTAOKULLARINDAKİ ÖĞRENCİLERİN MÜZİK DERSINE İLIŞKIN GÖRÜŞLERININ İNCELENMESİ. Abant İzzet Baysal Üniversitesi Eğitim Fakültesi Dergisi, 19(4), 1334-1346.

Aksu, K. (2018). Imam hatip lisesi ögrencilerinin okul dişı zamanlarını değerlendirme biçimleri üzerine sosyolojik bir araştırma. Ankara Üniversitesi.

Akyüz, H. (2018). Anadolu İmam Hatip Liseleri Hadis Dersi Öğretim Programı Ve Ders Kitabı Üzerine Bazı Mülahazalar. Aİ̈̈̈ Illahiyat Fakültesi Dergisi, 6(11), 1-14.

Altinyelken, H. K., Çayır, K., \& Agirdag, O. (2015). Turkey at a crossroads: critical debates and issues in education. Comparative Education, 51(4), 473-483. https://doi.org/10.1080/0305006 8.2015.1089076

Altıntaş, E. (2016). Öğrencilerde İmam-Hatip Lisesi Algısı (Batman Örneği). Hitit Üniversitesi.

Altıntaş, M. C. (2020). Worldviews and identity discernment of Turkish youth and the role of religious education: An investigation of imam-Hatip High Schools'senior students' meaningmaking of the world in the 21st Century. University College London.

Ankaralı, H. (2019a). Beyoğlu Anadolu İmam Hatip Lisesi Öğrencilerinde İnternet ve Sosyal Medya Bağımlılık Düzeyi, Başarı ile İlişkisi ve Bağımlılık Üzerine Etkili Faktörler. Kalemname, 4(8), 301-331.

Ankaralı, H. (2019b). Türkiye'de İmam Hatip Okulları Hakkındaki Halkın Bilgi Düzeyi, Algı Seviyesi ve İlişkili Faktörler. Kalemname, 4(8), 210-300.

Apaydın, Ö. (2018). İmam-Hatip Liselerinde Okutulan Dinî Mûsikî Dersinin Nicelik ve Nitelik Bakımından İncelenmesi. Talim: Journal of Education in Muslim Societies and Communities, 1(2), 219-256.

Aras, İ., \& Öztürk, V. (2019a). İmam Hatip Ortaokulu Din Kültürü Ve Ahlak Bilgisi Öğretmenlerinin Özel Alan Yeterlik Algılarının Çeşitli Değişkenler Açısından İncelenmesi. Dokuz Eylül Ünivesitesi Illahiyat Fakültesi Dergisi, (49), 49-90. https://doi.org/10.21054/deuifd.588062

Aras, İ., \& Öztürk, V. (2019b). İmam Hatip Ortaokulu Din Kültürü Ve Ahlak Bilgisi Öğretmenlerinin Özel Alan Yeterlilikleri. Türkiye Din Eğitimi Araştırmaları Dergisi, 7, 101-123. 
Arslan, M. (2018). İmam Hatip Okulu Öğretmenlerinin Örgütsel Kimlik Algılarının Bazı Değişkenler Açısından İncelenmesi. Birey ve Toplum, 8(1), 111-129.

Aşlamac1, İ. (2014). Pakistan Medreselerine Bir Model Olarak İmam-Hatip Okulları. İstanbul: Değerler Eğitimi Merkezi.

Aşlamac1, İ. (2018). İMAM HATIP LİSESİ ÖĞRENCILERINİN MESLEK DERSİ ÖĞRETMENLERININ YETERLIKLERINE İLIŞKİN ALGILARI. Hikmet Yurdu, 11(22), $87-106$.

Aşlamac1, İ., \& Eker, E. (2016). İmam-Hatip Lisesi Öğrencilerinin Okul Aidiyet ve Dinî Tutum Düzeyleri Arasındaki İlişkinin İncelenmesi. Değerler Ĕ̆itimi Dergisi, 14(32), 7-38.

Aşlamac1, İ., \& Eker, E. (2017). Parental Participation of Imam Hatip High-School Students in Children's Education: A Qualitative Study Based on School Administrators' Views. Talim: Journal of Education in Muslim Societies and Communities, 1(2), 153-185. https://doi. org/10.12738/talim.2017.2.0007

Aşlamac1, İ., \& Kaymakcan, R. (2017). A model for Islamic education from Turkey: the ImamHatip schools. British Journal of Religious Education, 39(3), 279-292. https://doi.org/10.1080 /01416200.2015.1128390

Aslan, C. (2019). Level of religiosity by School Type : A Study on Women in Turkey. Çukurova Üniversitesi Ĕgitim Fakültesi Dergisi, 48(1), 787-820. https://doi.org/10.14812/cufej.485856

Aslan, O. (2019). Imam Hatip Liselerinde Görev Yapan Meslek Dersi Öğretmenlerinin Karşilaştiklari Sorunlar Ve Çözüm Önerileri (Kastamonu İli Örneği). Kastamonu Üniversitesi.

Aydemir, M. A. (2017). Türkiye'de İmam Hatip/li Algısı: Bazı Göstergeler Bağlamında Sosyolojik Bir Değerlendirme. Talim: Journal of Education in Muslim Societies and Communities, 1(1), 5-27. https://doi.org/10.12738/talim.2017.1.0003

Aydın, M., \& Duran, A. (2014). İmam Hatip Liselerinde Dinsel Geleneklerin Öğretimi: Tespitler Ve Teklifler. Ondokuz Mayı Üniversitesi İlahiyat Fakültesi Dergisi, (37), 19-42.

Aydoğan, Z. (2019). Ergenlere yönelik din eğitiminde hayatın anlamı (İmam hatip liseleri düzce örneği). Hitit Üniversitesi Sosyal Bilimler Enstitüsü.

Baltacı, A. (2019a). İmam-Hatip Liselerinde Çalışan Öğretmenlerin Mesleki Sorunlarının Analizi ve Çözüm Önerileri. Illahiyat Tetkikleri Dergisi, 52(December), 241-264. https://doi.org/10.29288/ ilted.588197

Baltac1, A. (2019b). İmam-Hatip Lisesi Öğrencilerinin Değer Yönelimleri. Eskişehir Osmangazi Üniversitesi Illahiyat Fakültesi Dergisi, 6(11), 125-158.

Baltacı, A. (2019c). Okul Yöneticilerine Göre İmam - Hatip Liselerinde Karşılaşılan Sorunlar. Bilimname, 2019(40), 375-406.

Balyer, A., \& Özcan, K. (2020). School Principals 'Instructional Feedback to Teachers: Teachers' Views. International Journal of Curriculum and Instruction, 12(Special Issue), 295-312.

Batar, Y. (2017). "Din̂̂” Manipülasyonlar Karşısında İmam Hatip Okullarının Misyonu. Talim: Journal of Education in Muslim Societies and Communities, 1(1), 29-54. https://doi. org/10.12738/talim.2017.1.0005 
Batar, Y. (2019). İmam Hatip Lisesinde Çalışan Rehber Öğretmenlerin Öğrencilerin Beklenti ve Sorunlarına İlişkin Tespitleri. Mesned İlahiyat Araştırmaları Dergisi, 10(2), 381-423.

Bayezit, F. (2017). Yumuşak Güç Unsuru Olarak Uluslararası İmam Hatip Liseleri. Talim: Journal of Education in Muslim Societies and Communities, 1(2). https://doi.org/10.12738/ talim.2017.2.0015

Bayhan, S., \& Gök, F. (2017). Education policy in an era of neoliberal urbanisation: a case study of Istanbul's school relocations. British Journal of Sociology of Education, 38(4), 581-595. https:// doi.org/10.1080/01425692.2015.1113858

Bayram, F., \& Özkamalı, E. (2019). Lise Öğrencilerin Siber Zorbalık Yapma ve Siber Mağdur Olma Durumlarının İncelenmesi. İnönü Üniversitesi Eğitim Fakültesi Dergisi, 20(1), 303-318. https://doi.org/10.17679/inuefd.543251

Bekiroğlu, H., \& Okan, N. (2018). İmam Hatip Okullarıyla İlgili Yayımlanan Çalışmaların İncelenmesi: 2000-2018 Y1llar1 Aras1 Tezlerin Bir Meta Sentezi. Talim: Journal of Education in Muslim Societies and Communities. http://talimdergisi.com/: Önder İmam Hatipliler Derneği. https://doi.org/10.12738/talim.2018.2.0105

Berkant, H. G., Tuncer, M., \& Tanır, H. (2015). İmam Hatip Ortaokulunda Öğrencisi Bulunan Velilerin Okul Tercih Nedenlerine İlişkin Görüşleri. Journal of Educational Sciences, June, 178-194.

Bilecik, S. (2016). Eğitime siyasi ve ideolojik yaklaşımlar bağlamında köy enstitüleri ve imam hatip okullar1. Mütefekkir, 3(6), 329-347.

Boztepe, M. (2016). Öğretmenlerin Psikolojik Şiddet (Mobbing) Algıları İstanbul İli Anadolu Yakasında Bulunan Resmi Imam Hatip Liselerinde Bir Tarama. Maltepe Üniversitesi.

Budak, H. (2019). Teog Sınavında Başarılı Öğrencilerin İmam Hatip Lisesini Tercih Nedenleri ve Sosyal Kimlik İnşa Sürecinde İmam Hatip Lisesinin Rolü. Journal of International Social Research, 12(64), 438-459. https://doi.org/10.17719/jisr.2019.3366

Buyruk, H. (2020). The role of religious education in hegemony construction: the case of imam hatip schools in Turkey. Paedagogica Historica, 00(00), 1-18. https://doi.org/10.1080/003092 30.2020 .1762677

Çağlar, İ. (2015). Anadolu'dan Viyana'ya İmam Hatipler: Modernleşme , Diaspora ve Eleştiri. Sakarya University Journal of Education, 1(April), 81-94.

Çakır, R., Bozan, İ., \& Talu, B. (2004). Imam Hatip Liseleri: Efsaneler ve Gerçekler. İstanbul: TESEV Yayınlar1. Retrieved from http://www.tesev.org.tr/etkinlik/imam-hatipler.php

Çakmak, D. (2009). Pro-Islamic public education in Turkey: The imam-hatip schools. Middle Eastern Studies, 45(5), 825-846. https://doi.org/10.1080/00263200903135596

Çalışkanoğlu, Ş. (2018). İmam-Hatip Lisesi Öğrencilerinin Sorun ve Beklentileri (Çorum Örneği). Hitit Üniversitesi.

Can, C. (2017). Köy Enstitülerinden İmam-Hatiplere Eğitimde Hegemonya Mücadelesi. İstanbul: Libra.

Çavdar, G. (2019). Türk Eğitiminde Muhafazakârlı: 1950-60 Dönemi Köy Enstitüleri- ImamHatipler Örneği. Ondokuz Mayıs Üniversitesi. 
Çekçıkar, S. (2019). Ergenlerde benlik saygısı ve dini başa çıkma (imam hatip lisesi öğrencileri örneği). Marmara Üniversitesi.

Çekin, A. (2013). İmam Hatip Lisesi Öğrencilerinin Prososyal Davraniş Eğilimleri Üzerine Nicel Bir İnceleme. Uluslararası Sosyal Araştırmalar Dergisi, 53(9), 1689-1699. https://doi. org/10.1017/CBO9781107415324.004

Çelik, Ö. F. (2016). Katsayı Uygulamasının Kaldırılması Sonrasında Imam Hatip Lisesi Öğrencilerinin Davranış, Tutum Ve Özellikleri (Gaziantep Örneği). Uludağ Üniversitesi.

Çelik, Z., \& Gur, B. S. (2013). Turkey's Education Policy During the AK Party Era (2002-2013). Insight Turkey, 15(4), 151-176.

Çetin, İ. (2017). Anadolu İmam Hatip Liselerinde Öğrenim Gören Öğrencilerin Okula İlişkin Tutumlarinin Çeşitli Değişkenler Açisindan İncelenmesi. İstanbul Sabahattin Zaim Üniversitesi.

Çimen, E. (2019). İmam hatip lisesi ögrencilerinin benlik saygısı düzeylerinin bazı değişkenler açısından incelenmesi. Hitit Üniversitesi Sosyal Bilimler Enstitüsü.

Cin, F. M., Karlıdağ-Dennis, E., \& Temiz, Z. (2020). Capabilities-based gender equality analysis of educational policy-making and reform in Turkey. Gender and Education, 32(2), 244-261. https://doi.org/10.1080/09540253.2018.1484429

Çınar, F. (2013). İMAM HATIP LİSESİ ÖĞRETIM PROGRAMLARININ ANALİZİ ve KARŞILAŞTIRILMASI. Milli Eğitim Dergisi, 43(197), 180-208.

Çınar, F. (2018). İmam Hatip Liselerinden Beklentiler. Journal of International Social Research, 11(60), 1243-1259. https://doi.org/10.17719/jisr.2018.2870

Çırak-Kurt, S., \& Kalman, M. (2019). Probing School Image at High Schools: Scale Development and a Discriminant Analysis. International Journal of Contemporary Educational Research, 6(2), 243-260. https://doi.org/10.33200/ijcer.562969

Cornell, S. E. (2018). Headed East: Turkey'S Education System. Turkish Policy Quarterly, 16(4), $47-56$.

Coşkun, M. K., \& Şentürk, B. (2010). Gelenekçilikten 'Muhafazakar Modernliğe': İmam Hatip Okulları Örneği. Mülkiye, XXXIV(268), 249-263.

Daban, Z. (2019). Imam - Hatip Liselerinin Tercih Nedenleri. Denizli. Retrieved from http:// acikerisim.pau.edu.tr/xmlui/handle/11499/28021

Dag, N. (2018). Florida State University Libraries Turkey 's Imam-Hatip Schools : Threat to Secular Democracy or Model of Integration? Florida State University.

Dagdemir, R., \& Tevabil Aka, S. (2019). Comparative Study on Attitudes of Students Studying in Different Types of High Schools towards Physical Education and Sports Lesson. Asian Journal of Education and Training, 5(4), 609-615. https://doi.org/10.20448/journal.522.2019.54.609.615

Demir, R. (2019). İmam Hatip Lisesinde Öğrenim Gören Suriyeli Öğrencilerin Eğitim Sorunlar1: Kilis Örneği. Mustafa Kemal Üniversitesi Sosyal Bilimler Enstitüsü Dergisi, 19(44), 280-306.

Deniz, A. Ç. (2014). Tek Parti Döneminde Devrimsel Ric'atler: Bir Ric'at Örneği Olarak İmam Hatip Seminerleri Girişimi ve İmam Hatip Kurslarının Açılması. Uşak Üniversitesi Sosyal Bilimler Dergisi, 7(3), 95-110. 
Dertli, S. O. (2019). Imam-hatip lisesi son sını öğrencilerinin mesleki yeterlilik düzeyleri hakkındaki görüşleri (Çorum ili örneği). Hitit Üniversitesi Sosyal Bilimler Enstitüsü, Çorum.

Doğan, M. K., \& Yuret, T. (2015). Üniversitelere Yerleşmede Farklı Katsayı Uygulamasının Etkileri. Ankara Üniversitesi SBF Dergisi, 70(1), 195-220.

Duman, D. (2015). 1950 Seçimleri Öncesinde Cumhuriyet Halk Partisi'nin Politik Bir Manevrası Olarak İmam Hatip Kursları. Belgi Dergisi, (10), 1343-1360.

Durakbaşa, A., \& Karapehlivan, F. (2018). Progress and pitfalls in women's education in Turkey (1839-2017). Encounters in Theory and History of Education, 19, 70-89. https://doi. org/10.24908/eoe-ese-rse.v19i0.11915

Durmuş, M. E., \& Kahraman, M. A. (2016). İmam Hatip Lisesi Birinci Sınıf Öğrencilerinin Kur'an Dersine Yönelik Görüşlerinin Değerlendirilmesi. In International Congress on Political, Economic, and Social Studies (ICPESS-2016) (pp. 24-26). İstanbul.

Durmuşçelebi, M., \& Deliktaş, M. (2016). Meslek liselerinde yaşanan sorunlar ve öğretmenlerin tükenmişlik düzeyleri ile ilişkisi - Kayseri ili örneği. In Ĕgitim Bilimlerinde Yenilikler ve Nitelik Arayışı (pp. 225-240). https://doi.org/10.14527/9786053183563.015

Ekşi, H., Okan, N., \& Ayhan, A. S. (2018). İmam Hatip Lisesi Öğrencilerinin Karakter Gelişiminin Yordayıcısı Olarak Öz Düzenleme Becerisi ve Okul İklim Algısı. Talim: Journal of Education in Muslim Societies and Communities, 2(2), 209-241.

Emen, N. (2019). İmam-Hatip Liselerinin Misyon, Vizyon ve Değerler Bağlamında Karşılaştırılarak Değerlendirilmesi. Dumlupınar Üniversitesi Ĕ̆itim Bilimleri Enstitüsü Dergisi, 3(2), 14-28.

Emiroğlu, A., \& Uyanık, N. (2019). Atatürk Dönemi İmam-Hatip Mektepleri Üzerine Bir Değerlendirme. Mevzu - Sosyal Bilimler Dergisi, (1), 71-93.

Erdem, İ., \& Alpaydın, Y. (2017). İmam Hatip Lisesi Bünyesindeki İmam Hatip Ortaokullarıyla Müstakil İmam Hatip Ortaokullarındaki Örgüt Kültürünün İncelenmesi. Talim: Journal of Education in Muslim Societies and Communities, 1(2), 187-218. https://doi.org/10.12738/ talim.2017.2.0014

Erikoğlu, E. N. (2019). İmam hatip öğrencilerinin okul tercihlerine etki eden faktörler. Marmara Üniversitesi.

Erkan, R., \& Akçayöz, H. (2003). Siyasi İslam Tartışmaları Açısından İmam-Hatip Lisesi Öğrencilerinin Demokratik Tutum ve Davranışlarının İncelenmesi. Cumhuriyet Üniversitesi Sosyal Bilimler Dergisi, 27(2), 174-201.

Eroğlu, M. S. (2018). İmam Hatip Öğrencilerinin Müzik Algıları Üzerine Bir Araştırma (Afyonkarahisar Örneği). Afyon Kocatepe Üniversitesi.

Ertaş, H. (2019). İmam Hatip Ortaokulu Öğrencilerinde Peygamber Tasavvuru: Niğde Örneği. Van Illahiyat Dergisi, 7(10), 21-40.

Ertugay, R. (2017). İmam Hatip Liseleri Hadis Ders Kitabının Hadis İlmi Açısından Değerlendirilmesi. Kafkas Üniversitesi İlahiyat Fakültesi Dergisi, 4(8), 155-191.

Genç, M. (2019). İmam hatip okulları ve ilahiyat fakülteleri örneğinde din eğitiminde kalite sorunu. Türkiye Din Eğitimi Araştırmaları Dergisi, 7, 145-166. 
Gencer, N. (2019a). İmam Hatip Lisesi Öğrencilerinde Okul Aidiyet Duygusu (Çorum Örneği). Sakarya Üniversitesi İlahiyat Fakültesi Dergisi (SAUIFD), 21(39), 149-172. https://doi. org/10.17335/sakaifd.514384

Gencer, N. (2019b). İmam Hatip Lisesi Öğrencilerinin Özgüven Düzeyleri Hakkinda Nicel Bir Analiz. Bilimname, 2019(4), 407-440. https://doi.org/10.28949/bilimname.593973

Göcen, G., \& Kaya, Z. (2014). İMAM-HATIP LISELERINDE ÇALIŞAN ÖĞRETMEN VE YÖNETICILERIN OKUL İKLIM ALGISI VE BU ALGIYA ETKI EDEN FAKTÖRLER (ISTANBUL ÖRNEĞİ). OMUIFD: Ondokuz Mayis University Review of the Faculty of Divinity, (36), 67-102.

Gogus, A., \& Saygin, Y. (2019). Privacy perception and information technology utilization of high school students. Heliyon, 5(5), e01614. https://doi.org/10.1016/j.heliyon.2019.e01614

Göksu, M. Z. (2018). İmam Hatip Ortaokulları İle Diğer Devlet Ortaokullarının Değerler Ĕgitimi Açısından Karşılaştırılması (Erzincan İli Örneği). Recep Tayyip Erdoğan Üniversitesi.

Gontijo, L. C. B., \& Barbosa, R. S. (2020). Erdoğan's pragmatism and the ascension of AKP in Turkey: Islam and neo $\square$ Ottomanism. Digest of Middle East Studies, 29(1), 76-91. https://doi. org/10.1111/dome. 12205

Gültekin, H. (2019). Uşak İli Örneğinde İmam Hatiplerin Hadis Yeterlilikleri. Mevzu-Sosyal Bilimler Dergisi, (2), 323-361.

Günay, İ. (2019). İmam Hatip Liselerinde Okutulan Tefsir Dersinin Önemi, Sorunları, Öğretim Metotları ve Bazı Teklifler. Tefsir Araştırmaları Dergisi, 3(2), 357-383.

Güngen, A. R. (2013). Islamic Schools in Modern Turkey: Faith, Politics and Education. Turkish Studies, 14(3), 612-616. https://doi.org/10.1080/14683849.2013.833021

Gür, B. S. (2016). What Erdoğan really wants for education in Turkey: Islamization or Pluralisation? Retrieved from http://studies.aljazeera.n

Güven, N. (2017). Moral Maturity Levels of Imam Hatip High School Students: The Case of Ortakoy District. International Journal of Psychology and Educational Studies, 4(3), 42-52. https://doi.org/10.17220/ijpes.2017.03.005

Hasanova, S. (2018). A Qualitative Evaluation on Fiqh Education from İmam Hatip High Schools to Theology Faculties. SHS Web of Conferences, 48, 01054. https://doi.org/10.1051/ shsconf/20184801054

Hendek, A. (2019). Country report: Turkey. British Journal of Religious Education, 41(1), 8-13. https://doi.org/10.1080/01416200.2019.1532227

Junaedi, M. (2016). IMAM HATIP SCHOOL (IMAM HATIP LISESI): Islamic School in Contemporary Secular Turkey. Analisa, 1(1), 121. https://doi.org/10.18784/analisa.v1i1.219

Kalkan, Ü., Aksal, F. A., Gazi, Z. A., Atasoy, R., \& Dağl1, G. (2020). The Relationship Between School Administrators ' Leadership Styles, School Culture, and Organizational Image. SAGE Open, January-Ma, 1-15. https://doi.org/10.1177/2158244020902081

Kanburoğlu, Ü. B. (2013). İmam Hatip Lisesi Öğrencilerinin Benlik ve Kurum Algilari: "Öteki” Olmadan "İmam Hatipli” Olmak Mümkün mü? In M. Öcal (Ed.), 100. Yılında İmam-Hatip Liseleri (1st ed.). İstanbul: Ensar Neşriyat. 
Kara, F. R. (2016). IMAM HATIP ORTAOKULU ÖĞRENCİ VELILERININ BEKLENTILERİ. Selçık Üniversitesi.

Kara, F. R. (2017). Din Eğitimi Bağlamında Kademeli Eğitim Sistemi ve İmam Hatip Ortaokulları. Talim: Journal of Education in Muslim Societies and Communities, 1(1), 89-118. https://doi. org/10.12738/talim.2017.1.0001

Karasubaşı, Ö. A. (2019). Öğrenci Ve Mezunlarının Perspektifinden İmam Hatip Liselerinin Değerlendirilmesi. Tokat Gaziosmanpaşa Üniversitesi.

Karateke, T. (2010). IMAM-HATIP LISESI ÖĞRENCILERININ SORUN VE BEKLENTILERI (BATMAN ILI ÖRNEĞİ). Firat Üniversitesi. https://doi.org/10.1017/CBO9781107415324.004

Karateke, T. (2019). İmam Hatip Lisesi Öğrencilerinin İmam Hatip Lisesi, Meslek Dersi Öğretmeni ve İdarecilerine İlişkin Metaforik Algıları. Cumhuriyet İlahiyat Dergisi, 23(3), 1235-1256. https://doi.org/10.18505/cuid.620035

Karlidag-Dennis, E., McGrath, S., \& Stevenson, H. (2019). Educational policy-making and hegemony: monolithic voices from civil society. British Journal of Sociology of Education, 40(8), 1138-1153. https://doi.org/10.1080/01425692.2019.1647091

Kaya, N. (2019). Linking the learning and teaching geography: The gap between school and university in Turkey. Review of International Geographical Education Online, 9(1), 102-121. https://doi.org/10.33403/rigeo.546813

Kaya, Z. (2018). İlahiyat Dışında Lisans Eğitimi Planlayan İmam Hatip Lisesi Öğrencilerinin Meslek Dersleri İle İlgili Değerlendirmeleri Üzerine Nitel Bir Araştırma. İslam Medeniyeti Araştırmaları Dergisi, 3(1), 61-96. https://doi.org/10.20486/imad.429826

Kaymakcan, R., \& Aşlamac1, İ. (2011). İmam-Hatip Liseleri Literatürü Üzerine Bibliyografik Bir İnceleme. Değerler Ĕ̌itimi Dergisi, 9(22), 71-101.

Kervankaya, F. (2014). İmam Hatip Liselerinde Arapça Öğretimi Üzerine Bir Değerlendirme. Eskişehir Osmangazi Üniversitesi İlahiyat Fakültesi Dergisi, 1, 125-134.

Keyifli, Ş. (2017). Dinî İletişim Yeterliği Açısından Hitabet ve Mesleki Uygulamalar Dersi ile İlgili Bir Araştırma. Talim: Journal of Education in Muslim Societies and Communities, 1(2). https:// doi.org/10.12738/talim.2017.2.0011

Keyifli, Ş. (2019). İmam-Hatip okulu müdürlerinin değişimi yönetme yeterliği. Türkiye Din Eğitimi Araştırmaları Dergisi, (7), 167-187.

Kizilay, E., Yamak, H., \& Kavak, N. (2019). High school students that consider choosing science, technology, engineering, and mathematics (STEM) fields for their university education. Science Education International, 30(1), 4-10. https://doi.org/10.33828/sei.v30.i1.1

Koç, A. (2019). İmam hatip lisesi öğretmenlerinin örgütsel güven algıları. Türkiye Din Eğitimi Araştırmaları Dergisi, (8), 27-55.

Koç, A., \& Bastas, M. (2019). The evaluation of the project school model in terms of organizational sustainability and its effect on teachers' organizational commitment. Sustainability, 11(13), 1-23. https://doi.org/10.3390/su11133549

Koç, A., \& Baştaş, M. (2019). Project schools as a school-based management model. International Online Journal of Education and Teaching, 6(4), 923-942. 
Kocabey, H. (2019). Imam hatip liselerinde Arapça konuşma öğretimi (tespit ve değerlendirme). Marmara Üniversitesi.

Korkmaz, M. (2013). İmam Hatip Lisesi Öğrencilerinin Bu Okulu Tercih Süreçleri. Erciyes Üniversitesi İlahiyat Fakültesi Dergisi, 16(1), 7-40.

Korkmaz, M. (2018). İmam Hatip Meslek Dersleri Öğretmenlerinin Materyal Geliştirme Durumları. Bilimname, 2018(35), 175-216.

Korkut, M. (2017). Türkiye'de Öğrenim Gören Uluslararası İmam Hatip Lisesi Öğrencilerinde İslam Algis1. Talim: Journal of Education in Muslim Societies and Communities, 1(1), 119-142. https://doi.org/10.12738/talim.2017.1.0004

Kösterioğlu, İ., Çelen, Ü., \& Akın Kösterioğlu, M. (2019). Success purpose tendencies of high school students Lise öğrencilerinin başarı amaç yönelimleri. Journal of Human Sciences, 16(2), 662-678. https://doi.org/10.14687/jhs.v16i2.5603

Koyuncu, A., \& Birekul, M. (2014). Bir Model Arayışı Olarak Uluslararası İmam Hatip Liseleri. Muhfazakar Düşünce, 10(40), 171-188.

Kubat, M. (2019). İslâm Mezhepleri Tarihi Öğretimi Açısından İmam-Hatip Lisesi Müfredatının Değerlendirilmesi. E-Makalat Mezhep Araştırmaları Dergisi, 12(2), 212-255.

Küçük, M. (2018). Imam Hatip Ortaokullarında Farklıllkların Yönetimine Dair Öğretmen Görüşlerinin İncelenmesi. İstanbul Sabahattin Zaim Üniversitesi.

Kuloğlu, R. (2018). Yönetici Görüşlerine Göre İmam Hatip Ortaokullarındaki Hafızlık Projesinin Değerlendirilmesi. İstanbul Sabahattin Zaim Üniversitesi.

Macit, M. (2014). Sosyal medyada "imam hatipli” temsilleri: Kolektif bir kimlik söylemindeki sosyal-bilişsel izdüşümler. Atatürk Üniversitesi Türkiyat Araştırmaları Enstitüsü Dergisi, (51), 379-394.

Mermutlu, B. (2008). İmam-Hatip Liselerinin Seküler Açmazı. Akademik Araştırmalar Dergisi, $38,87-98$.

Mevlüt, K., \& Turan, İ. (2013). İlahiyat Fakültesi ve İmam-Hatip Lisesi Son Sınıf Öğrencilerinin Din Görevliliğine İlişkin Mesleki Yeterlilikleri (Samsun İli Örneği). Ondokuz Mayıs Üniversitesi Ilahiyat Fakültesi Dergisi, 34(34), 5-36.

Milli Eğitim Bakanlığı. (2019). Milli Eğitim İstatistikleri: Örgün Eğitim 2018/'19. Ankara. Retrieved from http://sgb.meb.gov.tr/meb_iys_dosyalar/2019_09/30102730_meb_istatistikleri_ orgun_egitim_2018_2019.pdf

Mücahit, M. (2016). Imam Hatip Lisesi Meslek Dersleri Öğretiminde Öğretmenin Rolü (Sivas İli Örneği). Cumhuriyet Üniversitesi.

Mücahit, M. (2017). Öğrencilerin gözüyle imam hatip lisesi meslek dersleri ve meslek dersleri öğretmenleri (Sivas ili örneği). CÜ Sosyal Bilimler Dergisi, 41(1), 73-99.

Ocal, M. (2007). From the past to the present: Imam and preacher schools in Turkey - An ongoing quarrel. Religious Education, 102(2), 191-205. https://doi.org/10.1080/00344080701285477

Öcal, M. (1998). Cumhuriyet döneminde Türkiye'de din eğitimi ve öğretimi. Uludă̆ Üniversitesi İlahiyat Fakültesi Dergisi, 7(1). 
Önder İmam Hatipliler Derneği. (2018). Gazetelerde İmam Hatiplere Bakış. İstanbul. Retrieved from https://onder.org.tr/Content/pdf/Papers//4b5bd0f1-7e94-4ef9-9450-1d479f24cc88.pdf

Önder, Y. K., \& Shamsuddin, M. (2019). Heterogeneous Treatment Under Regression Discontinuity Design: Application to Female High School Enrolment. Oxford Bulletin of Economics and Statistics, 81(4), 744-767. https://doi.org/10.1111/obes.12292

Örekli, M. (2018). Anadolu İmam Hatip Liseleri Meslek Dersleri Öğretmenlerinin Öğrenciler Tarafindan Epistemik Otorite Olarak Görülmesi Üzerine Nitel Bir Araştırma. Necmettin Erbakan Üniversitesi.

Ortahisar, S. (2019). İmam hatip okulları'nın Türk eğitim tarihindeki yeri. Ondokuz Mayıs Üniversitesi.

Özdemir, N., \& Yalçın, M. T. (2019). Examination of the Relationships between Academic Achievement and the Variables at the Levels of School and Students in Secondary Schools: Two-Level Path Analysis. TED E ĞITIM VE BILIM, 44(200), 93-116. https://doi.org/10.15390/ EB.2019.8056

Özdemir, Ş., \& Karateke, T. (2018). Öğrencilerin İmam Hatip Liselerini Tercih Etme Nedenleri (Elazı̆̆ Örneği). Ondokuz Mayıs Üniversitesi Illahiyat Fakültesi Dergisi, 45(December), 5-33.

Özturhan, F. (2019). İmam Hatip Lisesi Öğrencilerinin Güney Kore Dizileri İzleme Durumlarl ve Dizilerin Etkileri. Necmettin Erbakan Üniversitesi.

Özyiğit, M. (2018). Öğrencilerin İmam-Hatip Ortaokullarını Tercih Nedenleri. Pamukkale Üniversitesi.

Özyurt, Ş. (2015). Imam Hatip lisesi Öğrencilerinin Mesleki Yeterlilik Algıları. Gaziantep Üniversitesi.

Pak, S. Y. (2004a). Articulating the Boundary between Secularism and Islamism: The ImamHatip Schools of Turkey. Anthropology and Education Quarterly, 35(3), 324-344. https://doi. org/10.1525/aeq.2004.35.3.324

Pak, S. Y. (2004b). Cultural politics and vocational religious education: The case of Turkey. Comparative Education, 40(3), 321-341. https://doi.org/10.1080/0305006042000274827

Pehlivan, A. (2018). Manevi Bakım Ve Danışmanlı̆̆ın İmam Hatip Ortaokul Öğrencilerinin Ruh Sa ̆̆lı̆̆ Ve Manevi İyi Oluşlarına Etkisi. İzmir Katip Çelebi Üniversitesi.

Reed, H. A. (1955). Turkey's New Imam-Hatip Schools. Die Welt Des Islams, 4(2-3), 150-163. https://doi.org/10.1163/157006055X00047

Rutz, H. J. (1999). The Rise and Demise of Imam-hatip Schools: Discourses of Islamic Belonging and Denial in the Construction of Turkish Civic Culture. PoLAR: Political and Legal Anthropology Review, 22(2), 93-103. Retrieved from https://heinonline.org/HOL/P?h=hein. journals/polar22\&i=267

Sali, E. (2019). Imam hatip liselerindeki kız öğrencilerin sorunları ve beklentileri (İstanbulGüngören örneği). Bursa Uludağ Üniversitesi.

Sarfati, Y. (2015). Islamic Schools in Modern Turkey: Faith, Politics, and Education. British Journal of Middle Eastern Studies, 42(4), 684-686. https://doi.org/10.1080/13530194.2014.905293 
Sarı, M. (2019). Imam Hatip Liselerini Tercih Eden Öğrenci Ve Velilerin Beklentileri Ve Bu Beklentilerin Karşılanma Düzeyi (İstanbul/Pendik Örneği). Ankara Yıldırım Beyazıt Üniversitesi.

Sarpkaya, R. (2008). Köy Enstitüleri'nden Sonra İmam -Hatip Liseleri. Toplum ve Demokrasi, 2(3), 1-28.

Sel, T. (2019). 28 Şubat postmodern darbe sürecinde medyada algl yönetimi: imam hatip okullarl öznelinde eleştirel gazete haber çözümlemeleri. Marmara Üniversitesi.

Sevilmiş, S. (2019). Imam hatip ortaokulları hz. Muhammed'in hayatı dersi müfredatında yer alan âdâb-ı muâşseret konularının ögrenciler üzerindeki etkisi (6. 7. 8. sınıf istanbul örneği). Marmara Üniversitesi.

Sevinç, M. (2017). İmam hatip liselerinde dinî mûsikî eğitiminin tarihsel süreci ve öğretim programlarının karşılaştırılması. Journal of Faculty of Theology of Bozok University, 11, 153183.

Subaşı, N. (2004). İmam hatip (li) ler üzerine: Teolojik birikimin modern kaynakları. Değerler Eğitimi Dergisi, 2(6), 116-132.

V

Suna, E., Tanberkan, H., \& Özer, M. (2020). Changes in Literacy of Students in Turkey by Years and School Types: Performance of Students in PISA Applications. Eğitimde ve Psikolojide Ölçme ve Değerlendirme Dergisi, (April), 76-98. https://doi.org/10.21031/epod.702191

Suna, H. E., Tanberkan, H., Gür, B., Perc, M., \& Özer, M. (2020). Socioeconomic Status and School Type as Predictors of Academic Achievement. Journal of Economy Culture and Society, 61(1), 1-24. https://doi.org/10.26650/jecs2020-0034

Taluk, A. (2014). Imam Hatip Lisesi Öğrencilerinde Allah Tasavvuru (Iğdır Örneği). Iğdır Üniversitesi.

Tamer, M. (2019). Okul Yöneticilerinin Desteğiyle Oluşturulan Sosyal Sermayenin Okul Başarısına Etkisi. Selçuk Üniversitesi Edebiyat Fakültesi Dergisi, (41), 283-312. https://doi.org/10.21497/ sefad.586619

Terlemez, V. (2019). Imam hatip lisesi ögrencilerinin imam hatiplilik algısı ve deneyimlerinin incelenmesi. İstanbul Sabahattin Zaim Üniversitesi.

Toker, İ., \& Özcan, C. (2017). Laiklik ve Sekülerleşme Bağlamında İmam Hatip Liselerinin Dünü, Bugünü, Yarını. Eskiyeni, 35, 33-50.

Turan, İ., \& Vural, A. (2018). İMAM-HATİP LİSESİ SON SINIF ÖĞRENCILLERINNIN MESLEKİ YETERLIK ALGISI. Hitit Üniversitesi Sosyal Bilimler Enstitüsü Dergisi, 11(3), 1745-1760. https://doi.org/10.17218/hititsosbil.445930

Uçar, R., Polat, H., \& Altun, V. K. (2016). İmam Hatip Lisesi Öğrencilerinin Arapça Dersine Karş1 Tutumlarının Değerlendirilmesi. İnönü Üniversitesi İlahiyat Fakültesi, 7(2), 31-52.

Ünal, İ. Ö. (2008). Sakarya İlinde Imam Hatip Algisı. Sakarya Üniversitesi.

Uzun, K., \& Kemerli, Ş. (2019). Ortaöğretim Öğrencilerinin Devamsızlık Nedenleri: Fethiye İlçesi Örneği. Adnan Menderes Üniversitesi Eğitim Fakültesi Ĕ̆itim Bilimleri Dergisi, 10(2), 1-19. 
Yaman, G. (2016). Anadolu İmam-Hatip Lisesi Öğrencilerinin Arapça Öz-Yeterliklerine İlişkin Görüşleri: Isparta İli Örneği. Süleyman Demirel Üniversitesi.

Yanmaz, A. N. (2013). MEB İmam Hatip Öğrencilerinin Peygamber Tasavvuru. Cumhuriyet Üniversitesi.

Yiğit, Y. (2020). Anadolu İmam Hatip Lisesi Meslek Derslerinde Problem Çözme Becerisi Kazanma Amacına Erişim Düzeyi (Sivas İli Örneği). Eskiyeni, 40, 155-179. https://doi.org/10.37697/ eskiyeni.667837

Yıldırım, C. (2015). Imam hatip liselerinde okul kültürü algısı (Diyarbakır örneği). Dicle Üniversitesi.

Yıldız, H., \& Açak, M. (2019). Lise Öğrencilerinin Futbol Fanatiklik Düzeylerinin İncelenmesi. İn̈nü Üniversitesi Eğitim Fakültesi Dergisi, 19(3), 738-748. https://doi.org/10.17679/ inuefd. 454735

Yüksel, Y. (2016). İmam Hatip Liselerinde Kur'an Eğitimi Üzerine Bir Araştırma (Tekirdağ Örneği). Namık Kemal Üniversitesi Illahiyat Fakültesi Dergisi, 2(1), 9-29.

Zurnacı, İ. (2019). Çocuklarını İmam Hatip Ortaokuluna Gönderen Veliler Üzerine Betimsel Bir Araştırma Çorum Örneği. Hitit Üniversitesi. 